\title{
Is Sex Like Driving? Risk Compensation Associated with Male Circumcision in Kisumu, Kenya *
}

\author{
Nicholas Wilson ${ }^{\dagger}$, Wentao Xiong ${ }^{\ddagger}$, Christine Mattson ${ }^{\S}$
}

First draft: August 2011

Current draft: January 2012

\begin{abstract}
Mass adult male circumcision campaigns for HIV prevention are underway across much of Sub-Saharan Africa. However, concern remains about risk compensation associated with the reduction in the probability of HIV transmission per risky act. This paper examines the behavioral response to male circumcision in Kisumu, Kenya. Contrary to the presumption of risk compensation, we find that the response due to the perceived reduction in HIV transmission appears to have been a reduction in risky sexual behavior. We suggest a mechanism for this finding: circumcision reduces fatalism about acquiring HIV/AIDS and increases the salience of the tradeoff between engaging in additional risky behavior and avoiding acquiring HIV. We also find what appears to be a competing effect that does not operate through the circumcision recipient's belief about the reduction in the risk of acquiring HIV.
\end{abstract}

JEL classification: D81, D84, I18

Keywords: beliefs, HIV/AIDS, Kenya, male circumcision, risk compensation

*We thank Robert Bailey, Jon Bakija, Daniel Bennett, Ralph Bradburd, Andrew Foster, Bob Gazzale, Amar Hamoudi, Dan Korenblum, Kenneth Kuttner, Sara Lalumia, David Love, Emily Oster, Jonathon Robinson, Michael Rolleigh, Gil Shapira, Wei Sun, Harsha Thirumurthy, Rebecca Thornton, Tara Watson, Rachel Wilson, and conference participants at NEUDC 2011 at Yale University for many helpful comments. All errors are our own.

${ }^{\dagger}$ Department of Economics, Williams College. Corresponding author. Tel.: +1 4135974868 Fax: +1 413597

4045 E-mail: nlw3@williams.edu

${ }^{\ddagger}$ Harvard Business School.

$\S$ (Formerly) School of Public Health, University of Illinois, Chicago. 


\section{Introduction}

Experimental evidence from recent medical trials (Auvert et al 2005, Bailey et al 2007, Gray et al 2007a) demonstrates that medically performed male circumcision reduces the probability of femaleto-male transmission of HIV by as much as 76 percent. This finding has spurred plans for mass male circumcision campaigns for HIV prevention in a large number of Sub-Saharan African countries, the region of the world most affected by the HIV/AIDS pandemic. For example, the government of Tanzania is in the process of circumcising 2.8 million young males by 2016 (Plusnews 2011a). Similarly, the Bill and Melinda Gates Foundation is funding the circumcision of approximately 650,000 males in Swaziland and Zambia (Coghan 2009).

In addition to the mechanical effect of the reduction in the transmission probability, these campaigns may generate several behavioral effects. In particular, risk compensation is a major concern (e.g., Cassell et al 2006, Gray et al 2007b, WHO 2007). In response to the reduction in the probability of HIV transmission per unprotected coital act, circumcised men may choose to engage in higher levels of risky sex. Even if individuals are perfectly informed about the magnitude of the protective effect of male circumcision, this compensatory response would at least partly counteract the mechanical effect of the reduction in the transmission probability.

We examine risk compensation associated with male circumcision in a nested study in a randomized, controlled trial (RCT) in Kisumu, Kenya. In this nested study, individuals participating in a RCT designed to evaluate the efficacy of male circumcision for HIV prevention were recruited to participate in a study examining risk compensation. Seventy-four percent of individuals from the full study who were recruited to participate in the nested study actually participated in the nested study (Mattson et al 2008). Although uncircumcised men were slightly more likely to participate in the nested study, circumcised and uncircumcised men in the nested study generally appear to have had similar observable characteristics and behaviors at baseline aside from circumcision status. In addition to collecting information on their risky sexual behavior, the nested study surveyed individuals about their belief about whether male circumcision has a protect effect against acquiring HIV.

In contrast to the standard approach in the existing literature on male circumcision for HIV prevention, we emphasize that it is only those individuals who believe that male circumcision is 
protective who should engage in risk compensation. ${ }^{1}$ Risk compensation is a behavioral response that operates through a change in the riskiness of a particular activity that is actually perceived by the individual. Of course there may be a response to male circumcision for reasons other than the recipient's belief about its effect on HIV transmission (e.g., circumcision reduces other STIs which may result in increased demand for sexual activity or increased marketability among potential partners) and measuring this response is also of interest. Thus, in our empirical analysis we disaggregate the behavioral response to male circumcision by beliefs. We interpret the response to circumcision among non-believers as the non-beliefs channel and the response to circumcision among believers as the sum of the non-beliefs and beliefs (i.e., risk compensation) channels. The difference between these two estimates (i.e., the effect of circumcision among believers net of the effect among non-believers) measures the extent of risk compensation.

The results of our empirical analysis suggest that the behavioral response to circumcision among believers net of the response among non-believers was a reduction in risky sexual activity. That is, we find what appears to be a behavioral response that is the opposite of the risk compensation story. The response to circumcision among believers net of the response to circumcision among non-believers appears to have been a 10 to 20 percentage point reduction in the likelihood of having multiple sexual partners. Similarly, although there does not appear to have been a difference in condom use in the short term, after one year there was a significant increase in condom use among circumcised believers as compared to circumcised non-believers.

We suggest a mechanism for this finding: in a high HIV prevalence environment circumcision may reduce fatalism and increase the salience of the tradeoff between engaging in additional risky sexual behavior and avoiding acquiring HIV. In the absence of male circumcision, individuals in this environment may be likely to believe that they will acquire HIV with high probability at some point in their life, meaning that the expected marginal cost of additional risky sexual behavior may be relatively low. After receiving male circumcision, an intervention that lowers the femaleto-male HIV transmission probability by as much as 76 percent (Auvert et al 2005, Bailey et al 2007, Gray et al 2007a), individuals may no longer perceive engaging in a "normal" amount of risky sexual behavior as a death sentence. Thus, although male circumcision reduces the likelihood of HIV transmission, it may actually increase the expected marginal cost of risky sexual behavior by increasing the life expectancy of a circumcised male.

\footnotetext{
${ }^{1}$ To the best of our knowledge, Godlonton et al (2011) provides the only empirical analysis that focuses on risk compensation behavior among individuals who believe male circumcision is effective.
} 
This finding contrasts with the "Peltzman effect" documented in most of the previous economic literature on risk compensation (e.g., Peltzman 1975, Evans and Graham 1991, Keeler 1994, Dickie and Gerking 1997, Winston 2006). These studies mostly examine risk compensation associated with improvements in automobile safety technology and find evidence consistent with riskier behavior in response to safety improvements. ${ }^{2}$ Nonetheless, the divergent finding in the current analysis is consistent with the difference in the relative magnitude of the effect of the safety improvement on life expectancy. Although driving was more dangerous prior to the widespread availability and use of seatbelts in automobiles, presumably driving per se was not perceived as being particularly lifethreatening. Thus, it seems unlikely that seatbelts led to an increase in perceived life expectancy. In contrast, more than 15 percent of adults in our study setting, Kisumu, Kenya, are HIV positive, suggesting that a 51 to 76 percent reduction in the likelihood of HIV transmission generates a large increase in life expectancy for young adults. Our main finding is also consistent with the argument in Oster (2009) that lower life expectancies and lower incomes reduce the responsiveness of sexual behavior in Sub-Saharan Africa to the risk of HIV infection.

In addition to our primary empirical finding, our results indicate the existence of a behavioral response that was not due to a perceived reduction in the HIV transmission probability. Namely, circumcised males who did not believe circumcision is effective at reducing HIV transmission appeared to increase their risky behavior. Although by definition this cannot be due to risk compensation, this is a notable behavioral response to male circumcision. There are at least two possible explanations for this finding. First, circumcision reduces the likelihood of acquiring other STIs (Weiss et al 2006, Auvert et al 2009, Tobian et al 2009), including some with observable symptoms, possibly increasing the demand for sexual activity on the part of the recipient even though the recipient is not aware of the exact mechanism underlying this effect. Second, potential partners may prefer circumcised males (e.g., because the potential partners may be aware of the fact that male circumcision protects against HIV transmission or for aesthetic reasons). ${ }^{3}$ Because of the

\footnotetext{
${ }^{2}$ An important exception is Cohen and Einav (2003), which finds no association between automobile safety improvements and traffic accident fatalities among non-occupants (e.g., bicyclists or pedestrians), suggesting the lack of a compensatory response among drivers.

${ }^{3}$ Evidence from randomized controlled trials suggests that male circumcision may not directly reduce the likelihood of male-to-female transmission of HIV (Wawer et al 2009, Weiss et al 2009, Hallet et al 2011)). However, potential partners may still prefer circumcised males because a circumcised male may be less likely to be HIV positive. Among a survey of 110 women in Nyanza Province, 69 percent reported a preference for circumcised partners and the vast majority of respondents cited hygiene as the primary reason (Mattson et al 2008).
} 
existence of a non-beliefs mechanism linking circumcision to increased risky behavior, most of our specifications suggest there was no effect of male circumcision on risky sexual behavior on average. Nonetheless, we emphasize that the apparent behavioral response due to a perceived reduction in the probability of HIV transmission contradicts the presumption of risk compensation associated with male circumcision.

The rest of the analysis is organized as follows. Section 2 discusses medical evidence on the efficacy of male circumcision for HIV prevention and mass male circumcision campaigns currently underway in Sub-Saharan Africa. Section 3 discusses the data and Section 4 discusses the empirical strategy. Section 5 presents the results of the empirical analysis. Section 6 examines explanations for these results and implications for future research. Section 7 concludes.

\section{Male Circumcision for HIV Prevention}

The results of recent randomized controlled medical trials provide conclusive evidence that male circumcision reduces the likelihood of circumcised males acquiring HIV. Estimates of the biological prophylactic effect of male circumcision range from a 51 to 76 percent reduction in the femaleto-male HIV transmission rate (Auvert et al 2005, Bailey et al 2007, Gray et al 2007). ${ }^{4}$ These estimates are qualitatively consistent with the prior, observational evidence on the negative correlation between male circumcision rates and HIV prevalence (e.g., Bongaarts et al 1989, Moses et al 1990, Weiss et al 2000). Although male circumcision may not provide a direct protective effect against male-to-female transmission of HIV (Wawer et al 2009, Weiss et al 2009, Hallet et al 2011), it may indirectly reduce male-to-female transmission of HIV by reducing HIV prevalence among males.

This evidence on the biological efficacy of male circumcision for HIV prevention has encouraged the scale-up of mass male circumcision campaigns across many countries in Sub-Saharan Africa. The World Health Organization (WHO) recommends that medically performed male circumcision be part of a comprehensive HIV/AIDS prevention program. In particular, thirteen priority countries with high HIV prevalence and low circumcision rates have been advised to focus on scaling-up this intervention (WHO 2009). The WHO has provided financial and technical support to the priority

\footnotetext{
${ }^{4}$ Estimates of the overall probability of female-to-male transmission of HIV per unprotected discordant act in a population with low rates of male circumcision are approximately 0.001 (Gray et al 2001, Wawer et al 2005). By discordant, we mean discordant in HIV status: the reference individual is HIV negative and his partner is HIV positive.
} 
countries that responded with cooperation.

Kenya, the location of our study setting, is one of the thirteen priority countries and has recently circumcised large numbers of adult males. Although 85 percent of men in Kenya are circumcised, only 40 percent of men in Nyanza Province, the province with the highest HIV prevalence, are circumcised (WHO 2009). Thus, in 2008, the Kenyan government launched a national male circumcision campaign and circumcised more than 90,000 men (40,000 men in Nyanza Province) by the end of 2009. The government's goal is to circumcise the estimated 1.1 million uncircumcised men who remain in Kenya by 2013 (PlusNews 2010). As of December 2011, Kenya has circumcised approximately 350,000 men (PlusNews 2011b).

Despite enthusiastic support among policymakers, concerns remain about risk compensation associated with male circumcision (e.g., Cassell et al 2006, Gray et al 2007b, WHO 2007). If individuals respond to the lowered risk of HIV transmission per risky act by increasing the number of risky acts in which they engage, then the reduction in HIV incidence would be less than that predicted by the biological protective effect of a 51 to 76 percent reduction. In fact, this compensatory response may overwhelm the biological protective effect and lead to an increase in HIV incidence, particularly if individuals overestimate the prophylactic effect of male circumcision.

Several medical and public health studies have examined the behavioral response to male circumcision in an experimental setting (e.g., Agot et al 2007, Bailey et al 2007, Gray et al 2007a, Mattson et al 2008). In general, these studies find little-to-no evidence of behavioral disinhibition (i.e., increased propensity for risky sexual behavior) among circumcised males as compared to uncircumcised males. Because these studies do not disaggregate the behavioral response to circumcision by whether the recipient believes it is protective against HIV transmission, we do not interpret these studies as providing direct evidence on risk compensation. ${ }^{5}$ Instead, they provide evidence on the average effect among believers and non-believers. In a policy environment where individuals voluntarily select into mass adult male circumcision campaigns for HIV prevention if they believe circumcision is effective, the behavioral response among believers is of central importance.

To the best of our knowledge, Godlonton et al (2011) provides the only empirical analysis that focuses on risk compensation behavior among individuals who believe male circumcision is effective at reducing HIV transmission. ${ }^{6}$ In a field experiment in Malawi, Godlonton et al (2011) examine

\footnotetext{
${ }^{5}$ In an analysis of the behavioral response to circumcision, Mattson et al (2008) controlled for belief in the efficacy of male circumcision for HIV prevention. The current analysis extends the focus on beliefs in Mattson et al (2008) by allowing the response to circumcision to vary by beliefs instead of simply controlling for beliefs.

${ }^{6}$ Several other studies examine beliefs about the efficacy of male circumcision for HIV prevention. For example,
} 
risk compensation associated with receiving information on the efficacy of male circumcision for HIV prevention. They find that uncircumcised men reduce their risky sexual behavior in response to receiving this information, whereas circumcised men do not change their behavior in response to receiving this information. ${ }^{7}$ Although the effect of circumcision may differ from the effect of information, these findings suggest that individuals in mass male circumcision campaigns may not respond to circumcision by increasing their risky sexual behavior.

\section{Data}

We investigate the behavioral response to male circumcision using data from a nested study in a randomized controlled trial (RCT) conducted in Kisumu District, Kenya. ${ }^{8,9,10}$ The RCT recruited HIV negative, uncircumcised, sexually active males age 18-24. Between February 2002 and September 2005, the RCT successfully enrolled nearly 2,800 participants and assigned 1,391 to receive a medically performed circumcision and 1,393 to remain uncircumcised. ${ }^{11}$ The nested study recruited all 1,780 RCT participants enrolling between March 2004 and September 2005 and successfully enrolled 1,319 participants (i.e., 74 percent of eligible RCT participants). ${ }^{12}$ All participants received HIV testing and counseling at baseline and hence were aware of the fact that they were HIV negative at baseline.

A precondition for participating in the RCT was a willingness to receive a medically performed Mattson et al (2008). In addition, Westercamp et al (2011) surveyed women and uncircumcised men and examined the correlates of belief in the efficacy of male circumcision for HIV prevention as well as the implications for risk compensation.

${ }^{7}$ Perhaps surprisingly, the group that changed their behavior in response to the information (i.e., uncircumcised males) did not change their beliefs about the efficacy of male circumcision for HIV prevention. Similarly, the group that did not change their behavior in response to the information (i.e., circumcised males) did change their beliefs in accordance with the information about the efficacy of male circumcision for HIV prevention. This suggests that the mechanism generating the behavioral response was not risk compensation, which by definition operates through a change in beliefs.

${ }^{8}$ See Bailey et al (2007) for the original description of the RCT study design.

${ }^{9}$ See Mattson et al (2008) for the original description of the nested study design.

${ }^{10}$ Kisumu is located in Nyanza Province, where roughly 40 percent of males were circumcised at the time the RCT took place compared to 85 percent for Kenya as a whole (WHO 2009).

${ }^{11}$ Nearly 99 percent of participants were of Luo ethnicity, the main ethnic group in the study setting. Notably, the Luo are one of the few Kenyan ethnic groups that do not traditionally practice male circumcision. In Kisumu at the time of this study (i.e., 2004-05), approximately 10 percent of adult Luo males were circumcised (Buve et al 2000).

${ }^{12}$ Of these 1,319 individuals, ten were dropped from the final sample because of missing information for critical outcome variables (Mattson et al 2008). 
circumcision. As we shall see momentarily, it does not appear that individuals participated simply because they thought that circumcision would reduce the likelihood of HIV transmission. Moreover, consistent with this claim, existing medical evidence on the efficacy of male circumcision for HIV prevention at the time of the study was inconclusive. Monetary compensation, medical care (other than male circumcision), and possibly aesthetic reasons appear to be important motivations for participation. At each visit, RCT participants received 300 Kenyan shillings (approximately US \$4) and HIV testing and counseling (Bailey et al 2007). Participants in the nested study received an additional 150 Kenyan shillings at each visit (Mattson et al 2008).

Respondents in the nested study were interviewed at baseline, 6 months after initiation into the trial, and 12 months after initiation into the trial. ${ }^{13,14}$ The respondents also received HIV testing and counseling and risk reduction advice at each of these follow-ups, as well as one month after initiation into the study. We refer to the baseline survey as Visit 1, the 6 month follow-up as Visit 2, and the 12 month follow-up as Visit 3. At Visit 1, participants were asked to enumerate all partners since sexual debut. ${ }^{15}$ At Visits 2 and 3, participants were asked to enumerate all partners in the six months since the last interview. Participants were also asked questions about risky sexual behavior including for each partner whether he used a condom during the last sexual encounter. ${ }^{16}$ We use this information to construct a count variable measuring the number of partners the respondent had

\footnotetext{
${ }^{13}$ Among the 1,309 respondents, 1,001 (76\%) were successfully interviewed at 6 month follow-up and 1,007 (77\%) were successfully interviewed at 12 month follow-up. However, the interview rate did not differ significantly between the treatment and control groups (Mattson et al 2008). In addition, we estimate the parameters of Equation (1), but with an indicator variable for non-response at Visit 2 as the dependent variable (and repeat for non-response at Visit 3). None of the point estimates are statistically significant. Moreover, the point estimate for each parameter reverses sign for Visit 3 when compared to Visit 2. That is, the estimate of $\alpha_{1}$ in the non-response regressions is positive for Visit 2 and negative for Visit 3. For $\alpha_{2}$ and $\alpha_{3}$, the point estimates are positive (Visit 2) and negative (Visit 3), and negative (Visit 2) and positive (Visit 3), respectively. These results suggest that differential non-response does not explain our findings on the behavioral response to male circumcision.

${ }^{14}$ Respondents received HIV testing and counseling at each interview, as well as at clinical follow-ups at 1 month and 3 months after the baseline interview.

${ }^{15}$ Mattson et al (2008) reports information on risky sexual behavior in the six months preceding the baseline survey. To construct these measures, they use information on the start and end dates for the relationship with a given partner. We eschew this approach because it cannot identify self-reported behavior (.e.,g condom use at last sexual encounter with a given partner, or number of partners) that actually occurred during the six month period. For example, a relationship that began prior to the six month period and was not reported to have ended during the six month period may not have included any sexual intercourse during the six month period.

${ }^{16}$ Biomarker data were unavailable for the current analysis. However, Mattson et al (2008) demonstrates that in these data self-reported sexual behavior closely matches sexually transmitted infection (STI) outcomes.
} 
and an indicator variable for whether they had multiple partners. We also construct two measures of the propensity for using condoms. "Always use condom" is defined as the fraction of partners with which the respondent reported always using a condom. "Used condom last time" is defined as the fraction of partners with whom the respondent reported using a condom during their most recent sexual encounter.

In addition to basic demographic, socioeconomic, and sexual behavior information, each respondent in the nested study was asked whether they believed male circumcision was protective against acquiring HIV. Although respondents were told during recruitment that male circumcision might be protective against acquiring HIV, they were also told at that time that the medical evidence was inconclusive. At baseline, 57 percent of circumcised participants and 56 percent of uncircumcised participants believed in the efficacy of male circumcision. Respondents were asked this question again at Visits 2 and 3. During the course of the study period, there was a secular increase in the proportion of respondents believing circumcision reduces the risk of HIV infection. At Visit 2, 68 percent of circumcised respondents and 70 percent of uncircumcised respondents believed in the HIV prevention benefits of male circumcision. By Visit 3, these numbers had increased to 75 and 76 percent, respectively.

We proceed by investigating whether the randomization implemented in the full study remained effective in the nested study. Table 1 reports sample descriptive statistics at baseline in the nested study, disaggregated by circumcision assignment status. Circumcised and uncircumcised respondents appear to be nearly identical on most observable characteristics and past behavior at baseline. For example, circumcised respondents report 5.78 lifetime sexual partners and uncircumcised respondents report 5.74 lifetime sexual partners. Similarly, circumcised and uncircumcised respondents reported using a condom at last intercourse 6.6 and 6.7 percent of the time, respectively. For none of the measures of past sexual behavior or socioeconomic characteristics is there a statistically significant difference between circumcised and uncircumcised respondents. Notably, less than 10 percent of respondents were married or cohabiting. The lack of noticeable differences at baseline in behavior and observable characteristics by circumcision assignment status suggests that the randomization implemented in the full study remained effective in the nested study. However, circumcised and uncircumcised respondents differed on one dimension at baseline: prevalent sexually transmitted infections (STIs). ${ }^{17}$ By prevalent, we mean infected at baseline, not during the

\footnotetext{
${ }^{17}$ Although Mattson et al (2008) reports a statistically significant difference in employment status at baseline by circumcision assignment, we find no statistically significant difference in employment status by circumcision assign-
} 
course of the study. Although biomarker data were unavailable for the current analysis, Mattson et al (2008) reports that in the nested study 10 percent of circumcised men had a prevalent sexually transmitted infection (STI) at baseline compared to 7 percent of uncircumcised men.

Although the data largely suggest that the randomization implemented in the full study remained effective in the nested study, there is evidence of differential selection into the nested study based on observable characteristics. ${ }^{18}$ As compared to the full RCT, participants in the nested study were more likely to be circumcised ( $53 \%$ versus $50 \%$, p-value $=0.01)$, were more educated ( $58 \%$ completed secondary school versus $53 \%$, p-value $=0.03)$, were younger $(46 \%$ were between the ages of $18-20$ versus $41 \%$, p-value $=0.03)$, and were more likely to be unemployed $(67 \%$ versus $60 \%$, p-value $=0.02)$ (Mattson et al 2008). However, there were no statistically significant differences between the full RCT and the nested study in the number of lifetime sexual partners, in the number of partners in the past six months, or in sexually transmitted infections (STIs) at baseline (Mattson et al 2008).

\section{Empirical Strategy}

Our empirical strategy emphasizes the role of beliefs in the process determining risk compensation. We interpret the response to circumcision among non-believers as the non-beliefs channel and the response to circumcision among believers as the sum of the non-beliefs and beliefs (i.e., risk compensation) channels. Thus, we measure the extent of risk compensation by measuring the response to circumcision among believers net of the response among non-believers. The primary empirical specification is:

$$
\text { risky }_{i t}=\alpha_{0}+\alpha_{1} \text { circumcised }_{i}+\alpha_{2} \text { believe }_{i t}+\alpha_{3} \text { circumcised }_{i} \times \text { believe }_{i t}+\epsilon_{i t}
$$

where risky $_{i t}$ denotes the risky sexual behavior of individual $i$ over reference period $t$, circumcised $_{i}$ is an indicator variable equal to one if individual $i$ was assigned to receive circumcision, and believe $_{i t}$ is an indicator variable equal to one if individual $i$ believed in the protective benefits ment ( $48 \%$ versus $50 \%$ for uncircumcised and circumcised respondents, respectively, p-value=0.36). One possible explanation for this discrepancy is that Mattson et al (2008) may have defined employment status using information on reported occupation.

${ }^{18}$ We note that the full study was not necessarily statistically representative of young men Kisumu, Kenya. 
of male circumcision at the beginning of reference period $t .{ }^{19}$ The parameter $\alpha_{1}$ is the effect of circumcision on risky sexual behavior independent of the beliefs mechanism. The parameter $\alpha_{2}$ simply captures the difference in risky sexual behavior between believers and non-believers. Our interpretation of risk compensation indicates that $\alpha_{3}$ is the parameter that measures the extent of risk compensation. That is, it is the response to circumcision among believers net of the response among non-believers. We estimate the parameters of this regression equation using ordinary least squares (OLS) and report heteroskedasticity robust standard errors.

To further illuminate the validity of our empirical strategy, we examine the baseline data in the nested study along two more dimensions. First, Table 2 reports descriptive statistics at baseline disaggregated by belief at baseline. For most measures of past sexual behavior and most socioeconomic characteristics believers and non-believers appear to be very similar. However, believers were 3 percentage points more likely to have had multiple partners in their lifetime ( $\mathrm{p}$-value $=0.03$ ) and were 0.27 years younger on average $(\mathrm{p}$-value $=0.01)$ than non-believers. Under the assumption that the source of this heterogeneity across belief status is time invariant or at least does not evolve differentially by circumcision status, then the parameter $\alpha_{2}$ in Equation (1) should address this potential source of bias.

Second, Table 3 reports descriptive statistics at baseline disaggregated by the interaction of circumcision assignment and belief at baseline. Within a given belief group, for every measure of past sexual behavior or socioeconomic characteristics circumcised respondents are statistically indistinguishable from uncircumcised respondents. Moreover, as shown in Column (7) there are no statistically significant differences by belief status in the difference between circumcised and uncircumcised respondents. The results in Table 3 suggest that our primary empirical specification is unlikely to generate a spurious (i.e., non-causal) association between risky behavior during the course of the nested study and the interaction between circumcision assignment and belief about the efficacy of male circumcision for HIV prevention. Nonetheless, we conduct a more formal placebo test in Section 5.3.

\footnotetext{
${ }^{19}$ To clarify, risky behavior is measured over a six month interval and belief is recorded at the beginning of that interval.
} 


\section{Results}

\subsection{Risk compensation}

Before turning to the regression analysis, we present evidence on mean behavior at Visits 2 and 3, disaggregated by the interaction of circumcision assignment and belief about the efficacy of circumcision for HIV prevention. Table 4 reports these statistics, the difference between circumcised and uncircumcised believers, the difference between circumcised and uncircumcised non-believers, and the difference therein. Panel A presents the results for Visit 2 and Panel B presents the results for Visit 3. In general, these results suggest that the response to circumcision due to the perceived reduction in HIV transmission was a reduction in risky sexual behavior, contrary to the presumption of risk compensation. These results also suggest a response to circumcision that was not due to a perceived reduction in HIV transmission: among non-believers, circumcision was associated with riskier sexual behavior.

To fix ideas, consider Visit 2. Circumcised believers had fewer partners and were less likely to have had multiple partners than were uncircumcised believers (1.49 versus 1.58 and 36 percent versus 40 percent, respectively), although these differences are not statistically significant. However, among non-believers, circumcision was associated with more sexual partners and a greater likelihood of multiple partners (1.64 versus 1.40 ( $\mathrm{p}$-value $=0.07)$ and 43 percent versus 34 percent ( $\mathrm{p}$-value $=0.06)$, respectively). Thus, circumcision appears to have increased risky sexual behavior among non-believers. By subtracting this effect from the difference in risky sexual behavior associated with circumcision among believers, we can recover the response to circumcision due to the perceived reduction in HIV transmission. Column (7) in Table 4 presents the estimated response among believers net of the response among non-believers. For all outcomes aside from condom use at Visit 2, these results suggest that the response to circumcision due to a perceived reduction in HIV transmission was a decrease in risky sexual behavior (p-valuej0.10 for all outcomes aside from condom use at Visit 2).

Table 5 presents the main regression results. We begin by examining the evidence on risk compensation. As discussed in the previous section, we interpret the estimate of $\alpha_{3}$ in Equation (1) as the extent of risk compensation.

The estimates in Table 5 suggest a behavioral response to male circumcision that is contrary to the presumption of risk compensation. On the whole, the estimates for the circumcised-believe interaction indicate that the response to circumcision among believers net of the response among 
non-believers appears to have been a reduction in risky sexual behavior. For example, the response to circumcision among believers net of the response among non-believers appears to have been a 0.324 reduction in the number of partners as reported at Visit 2 (significant at the 10 percent level). The estimated 0.129 reduction in the likelihood of multiple partners (significant at the 5 percent level) suggests that there was a reduction on the intensive margin (i.e., particularly risky behavior) and not just the extensive margin. There is no evidence of an effect on condom use at Visit 2 according to either of our condom use measures. However, recall error may mean that these measures are noisier than the data on the number of partners.

Columns (5) through (8) repeat the analysis for Visit 3. In general, we find larger estimated responses at Visit 3 than at Visit 2. For example, the magnitude on the circumcised-believe interaction in the multiple partners regression increases in absolute value from -0.129 to -0.180

and is statistically significant at the 5 percent level and not just the 10 percent level. Similarly, the point estimates in the condom use regressions increase in magnitude and become statistically significant at the 10 percent level or smaller. One interpretation of this pattern is that individuals found it easier to adjust their behavior over a longer time horizon (i.e., 12 months instead of 6 months), possibly because existing relationships constrained the response in the short term.

\subsection{Effect of circumcision independent of beliefs}

The coefficient estimates for circumcised (i.e., the estimate of $\alpha_{1}$ in Equation (1)) in Table 5 measure the behavioral response to circumcision separate from the risk compensation mechanism. These estimates suggest that circumcision affected behavior aside from through its effects on the recipients' beliefs about the marginal cost of risky sexual behavior. The effect of circumcision on risky behavior through these non-beliefs mechanisms appears to have been an increase in the number of partners and in the likelihood of multiple partners at Visit 2 and at Visit 3. For example, the effect of circumcision through the non-beliefs channel was a 0.237 increase in the number of partners at Visit 2 and a 9 percentage point increase in the likelihood of multiple partners at Visit 2. Although these estimated responses through the non-beliefs channel are smaller than those documented as operating through the beliefs channel, they are statistically significant at (at least) the 10 percent level. Similar to the beliefs channel, there does not appear to have been an effect of circumcision through these non-beliefs mechanisms on condom use at Visit 2 and the non-beliefs effect of circumcision at Visit 3 appears to have been a reduction in the likelihood of condom use. For example, the effect on "alway use condom" was approximately a 15 percentage point increase 
in the likelihood of consistent condom use.

\subsection{Placebo test}

Information on risky sexual behavior engaged in prior to the study period provides a placebo test for the behavioral response to male circumcision. If the randomization of circumcision implemented in the full study remained effective in the nested study and if beliefs at baseline were exogenous to the process determining risky behavior during the course of the study, then we should not see any "effect" of circumcision through either the beliefs or non-beliefs channels. Table 6 presents evidence on this issue by showing the results of regressing past risky sexual behavior as reported at baseline (i.e., Visit 1) on circumcision assignment, belief about the efficacy of male circumcision at baseline, and the interaction thereof. Columns (1) through (4) report the results for the full sample of respondents at Visit 1. Columns (5) through (8) restrict the regression sample to those respondents at Visit 1 who also show up at Visit 2.

In general, the results of this placebo test are much smaller point estimates than in Table 5 and none of the terms are statistically significant. For example, the point estimates on circumcised and the circumcised-believe interaction in the multiple partners regression using the full sample (i.e., Column (2) of Table 6) are -0.006 and 0.027 , respectively, each a full order of magnitude smaller than the comparable point estimates from Table 5. Although the point estimates in the number of partners regressions in Table 6 are roughly as large as in Table 5, the definition of this variable differs between the baseline survey and Visits 2 and 3. At baseline, this variable refers to lifetime number of sexual partners, whereas at Visits 2 and 3 it refers to number of partners during the six months since the previous interview date.

\subsection{Robustness checks}

We proceed by investigating the robustness of our main results to including additional regressors. Table 7 presents the results of this exercise. In general, the estimated responses to circumcision through the risk compensation channel and through the non-beliefs channel are very similar to those presented in Table 5. The exceptions to this pattern are that the point estimates on the circumcised-believe interaction in the Visit 3 condom regressions become somewhat attenuated, so the effect in the "always use condom" regression becomes statistically insignificant and the effect in the "used condom last time" regression is now only significant at the 10 percent level.

A remaining concern about the results presented thus far is that "believe" is simply proxying for 
some other characteristic that determines the behavioral response to male circumcision rather than capturing the extent of risk compensation. For example, it may be the case that more educated males have different beliefs from less educated males and more more educated males may respond differently to circumcision. Table 8 helps investigate the basis for this concern by reporting the correlates of belief in the prevention benefit of circumcision. Although these OLS regressions do not provide strong support to the hypothesis that belief is simply proxying for some other important determinant of the response to circumcision, there is some evidence that belief is correlated with observable characteristics. Namely, older males appear to be less likely to believe in the prevention benefits of circumcision at baseline and at Visit 2 than are younger males (significant at the 1 percent and 5 percent levels, respectively). Similarly, income is correlated with belief at Visit 2 (significant at the 5 percent level). However, the general pattern in Table 8 is that the point estimates are small relative to the effects documented for circumcised and the circumcised-believe interaction, and the majority of the point estimates are not statistically significant.

In any case, we allow the response to male circumcision to vary along dimensions other than believer/non-believer. Table 9 presents the results of this analysis for number of partners (in Panel A) and multiple partners (in Panel B) as reported at Visit 2. Column (1) replicates the primary specification in Table 5. In Column (2), we allow the behavioral response to circumcision to vary by age and report estimates of the three main parameters (i.e., $\alpha_{1}, \alpha_{2}$, and $\alpha_{3}$ ) as well as estimates of the effects of age and the circumcised-age interaction. We repeat this analysis using married/cohabit instead of age in Column (3), years of schooling in Column (4), employed in Column (5), and average monthly income in Column (6). Throughout, the results of this analysis suggest that it is differences in beliefs about the efficacy of male circumcision for HIV prevention that drive the behavioral response to circumcision among believers as compared to non-believers. In none of the regressions in Table 9 does allowing the response to circumcision to vary by another observable characteristic substantially affect the point estimate on the circumcised-believe interaction or the associated standard error. Moreover, point estimates for the additional interactions (e.g., the circumcised-age interaction) tend to be quite small in magnitude as compared to those on the circumcised-believe interaction and are rarely statistically significant.

Table 10 repeats this analysis for "always use condom" and "used condom last time" at Visit 2. Tables 11 and 12 examine the robustness of the Visit 3 results. In general, these results are consistent with the pattern of stable point estimates and standard errors observed in Table 9 . 


\subsection{Average response to circumcision}

Although our empirical approach and findings appear to be unique among existing analyses of the behavioral response to male circumcision, our findings are not inconsistent with previous research on the behavioral response to male circumcision. In fact, a weighted average of the responses operating through the beliefs and non-beliefs channels is quite similar to the findings presented in the previous literature on this topic (e.g., Agot et al 2007, Bailey et al 2007, Gray et al 2007a, Mattson et al 2008) which indicate no difference between circumcised and uncircumcised males in risky behavior at follow-up visits. ${ }^{20}$ Nonetheless, we emphasize that what we learn about human behavior and the associated policy implications are substantively different.

Table 13 presents our estimates of the average response to male circumcision in our study setting. Panel A shows the results from a simple regression with no controls. In Panel B we control for belief in the efficacy of male circumcision for HIV prevention. In Panel $\mathrm{C}$ we also include the demographic and socioeconomic controls from our prior analysis. Throughout, the estimated average response to circumcision tends to be statistically insignificant and small. The estimated average response to circumcision is statistically significant only for "always use condom" at Visit 3 and for "used condom last time" at Visit 3 with the full set of controls. Although the Visit 3 condom use results suggest a five to eight percentage point reduction in the likelihood of consistent condom use, the other point estimates tend to be substantially smaller than either of the two effects documented in Table 5.

\section{Discussion}

The results of our empirical analysis suggest a behavioral response operating through beliefs that is contradictory to the presumption of risk compensation. This finding is somewhat puzzling given the fact that circumcision reduces the likelihood of HIV transmission. However, in a high HIV prevalence environment, a large reduction in the likelihood of HIV transmission may affect the marginal cost of risky sexual behavior for another reason: circumcision may reduce fatalism about acquiring HIV and increase the salience of the tradeoff between engaging in additional risky behavior and avoiding acquiring HIV.

Although we provide evidence rejecting several other possible stories, we recognize that beliefs are not randomly assigned so we interpret this result with caution. It would be useful to have

\footnotetext{
${ }^{20}$ Several of these studies do document a modest secular decrease in risky behavior over the course of the study.
} 
information on other investment decisions that might change if an individual's time horizon changes to help corroborate the mechanism we suggest for this finding. Unfortunately, although our data are uniquely suited for our purposes in other regards they do not contain this information. In any case, we demonstrate that if the mechanism we suggest is not correct, then the alternative mechanism is not one that is manifest as a differential response to circumcision by age, marital status, education, employment status, or income.

In addition to our main finding, our results suggest that there was a behavioral response to circumcision that did not operate through beliefs on the part of the circumcision recipient. The independent response to circumcision through this channel appears to have been an increase in risky sexual activity. One potential explanation for this finding is that demand for circumcised partners may be higher than that for uncircumcised partners, possibly because potential partners of the circumcised individuals believe that circumcision is effective at reducing HIV transmission. Likewise, potential partners may have an aesthetic preference for circumcised partners. Another possible explanation for this finding is that circumcision reduced the prevalence of other STIs, potentially increasing demand for circumcised males as well as increasing their demand for sexual activity. ${ }^{21,22}$ Among a survey of 110 women in Nyanza Province, 69 percent reported a preference for circumcised partners and the vast majority of respondents cited hygiene as the primary reason (Mattson et al 2005). ${ }^{23}$

Under several of these possible explanations for this secondary finding, the non-beliefs circumcision effect may be greatly diminished in the context of mass male circumcision campaigns. These campaigns aim to circumcise nearly all males in a given location. If everyone were circumcised, then possible partner preference for circumcised males would not be manifest as additional risky behavior for circumcised males. However, if the STIs explanation is correct and reducing STIs actually increases demand for sexual activity on the part of the individual who had fewer STIs, then we may still expect this effect in the context of a mass male circumcision campaign.

\footnotetext{
${ }^{21}$ Male circumcision appears to reduce the likelihood of the recipient acquiring HSV-2 (Weiss et al 2006, Tobian et al 2009), HPV (Auvert et al 2009, Tobian et al 2009), syphillis (Weiss et al 2006), and chancroid (Weiss et al 2006). For most bacterial STIs, male circumcision does not appear to convey a prophylactic effect on the recipient (Laumann et al 1997, Moses et al 1998, Dave et al 2003, Ritchers et al 2006, Dickson et al 2008, Millet et al 2008, Mehta et al 2009).

${ }^{22}$ Anecdotal evidence from fieldwork for the nested study suggests an increase in demand for sexual activity on the part of circumcision recipients. Many circumcised recipients stated they were eager to try out sex again now that they were circumcised.

${ }^{23}$ See Westercamp and Bailey (2007) for a review of studies of acceptability of male circumcision for HIV prevention.
} 
Two important areas for future research are the behavioral response among females and the response to an actual mass circumcision campaign. Existing research suggests that male circumcision may not directly reduce the likelihood of male-to-female transmission of HIV (Wawer et al 2009, Weiss et al 2009, Hallet et al 2011). ${ }^{24}$ However, individuals may be unaware of the potential gender difference in the protective effects of circumcision. Examining the response among females may also illuminate the potential role of partner preference for circumcised males. Because of the scale of mass male circumcision campaigns, they may be less likely to affect behavior through mechanisms based on partner preference for circumcised males. Moreover, it is important to evaluate a policy that has taken a central place in the efforts to ameliorate the HIV/AIDS pandemic.

\section{Conclusion}

This paper examines risk compensation associated with male circumcision using data from a nested study in a randomized controlled trial conducted in Kisumu, Kenya. We emphasize the role of beliefs in the process determining risk compensation. In our interpretation, it is only those individuals who believe circumcision is effective at preventing HIV transmission who are at risk of demonstrating this compensatory response.

Our empirical analysis yields two key findings. First, contrary to the presumption of risk compensation, we find that the behavioral response to the perceived reduction in HIV transmission probability in this study setting appears to have been a reduction in risky sexual behavior. Second, we find that independent of the beliefs mechanism, circumcision in this study setting appears to have increased risky sexual behavior. Because circumcision was randomized in the RCT rather than in the nested study and beliefs were not randomly assigned, we caution against interpreting these results as definitive. Nonetheless, the circumcised and uncircumcised men in the nested study appear to have had similar observable characteristics and past behaviors at baseline and we show that the differential response to circumcision by belief is robust to a host of additional interactions.

Several policy implications follow from our results. Our first key finding suggests that circumcision may generate a behavioral response that reinforces the mechanical prevention benefit. This response is likely to be larger in medium-to-high HIV prevalence populations that may have a fatalistic perspective on risky sexual behavior prior to male circumcision. In contrast, our second

\footnotetext{
${ }^{24}$ If male circumcision is effective at reducing HIV prevalence, then male circumcision may indirectly reduce maleto-female transmission through the reduction in HIV prevalence.
} 
key finding suggests that circumcision may actually lead to increased risky sexual behavior among individuals who do not believe in its protective effect. ${ }^{25}$ Fortunately, widespread information campaigns associated with mass male circumcision campaigns underway in much of Sub-Saharan Africa should mean that few individuals who choose to actually receive circumcision will fail to believe in its protective effects. This suggests that the net effect of mass adult male circumcision campaigns in higher HIV prevalence populations may be a reduction in HIV transmission, as the behavioral response may reinforce the biological effect. However, further research is required because there is little empirical evidence on the effects of an actual mass male circumcision campaign.

More generally, our results also inform two broader topics in economics. First, in contexts where individuals may not have complete information about the magnitude of changes in health production technologies, empirical tests of risk compensation that do not pay careful attention to the role of beliefs may tend to understate the degree of actual behavior change. Second, to the extent that the mechanism we suggest underlies our main result is correct, then changes in time horizon (e.g., life expectancy) may generate substantial changes in consumption decisions.

\footnotetext{
${ }^{25}$ Although believers shared this response operating through a non-beliefs channel, the estimated net effect among believers generally was zero, not an increase in risky behavior (see Table 5 for tests of the joint significance of the beliefs and non-beliefs channels).
} 


\section{References}

Agot, Kawango, James Kiarie, Huong Nguyen, Johannes Odhiamb, TM Onyango, Noel Weiss. 2007. Male circumcision in Siaya and Bondo Districts, Kenya: prospective cohort study to assess behavioral disinhibition following circumcision. Journal of Acquired Immune Deficiency Syndromes, 44: 6670 .

Auvert, Bertran, Dirk Taljaard, Emmanuel Lagarde, Joelle Sobngwi-Tambekou, Remi Sitta, and Adrian Puren. 2005. Randomized, controlled intervention trial of male circumcision for reduction of HIV infection risk: The ANRS 1265 Trial. PLoS Med 2(11): e298.

Auvert, Bertran, Joelle Sobngwi-Tambekou, Ewalde Cutler, Marthi Nieuwoudt, Pascale Lissouba, Adrian Puren, and Dirk Taljaard. 2009. Effect of male circumcision on the prevalence of high-risk human papillomavirus in young men: Results of a randomized controlled trial conducted in Orange Farm, South Africa. Journal of Infectious Diseases 199(1):1419.

Bailey, Robert, Stephen Moses, Corette Parker, Kawango Agot, Ian Maclean, John Krieger, Christopher Williams, Richard Campbell, and Jeckoniah Ndinya-Achola. 2007. Male circumcision for HIV prevention in young men in Kisumu, Kenya: A randomised controlled trial. The Lancet, 369(9562):643-56.

Bongaarts John, Priscilla Reining, Peter Way, Francis Conant. 1989. The relationship between male circumcision and HIV infection in African populations. AIDS, 3: 37377.

Buve, Anne, Bertran Auvert, Emmanuel Langarde, Maina Kahindo, Richard Hayes, and Michel Carael. 2000. Male circumcision and HIV spread in Sub-Saharan Africa. XIII International Conference on AIDS: Durban, South Africa; July 9-14, 2000. Abstract MoDrC192.

Cassell, Michael, Daniel Halperin, James Shelton, and David Stanton. 2006. Risk compensation: the Achilles heel of innovations in HIV prevention? British Medical Journal, 332(7541): 605-07.

Coghlan, Andy. 2009. Bill Gates helps fund mass circumcision programme. New Scientist, Health. June 15, 2009.

http://www.newscientist.com/article/dn17312-bill-gates-helps-fund-mass-circumcision-programme.html

Cohen, Alma and Liran Einav. 2003. The effects of mandatory seat belt laws on driving behavior and traffic fatalities. Review of Economics and Statistics, 85(4): 828843. 
Dave, Sangeeta, Kevin Fenton, Catherine Mercer, Bob Erens, Kaye Wellings, Anne Johnson. 2003. Male circumcision in Britain: finding from a national probability sample survey. Sex Transm Infect, 79: 499-500.

Dickson, Nigel, Thea van Roode, Peter Herbison, Christine Paul. 2008. Circumcision and risk of sexually transmitted infections in a birth cohort. J Pediatr 152:383-387.

Dickie, Mark and Shelby Gerking. 1997. Genetic risk factors and offsetting behavior: The case of skin cancer. Journal of Risk and Uncertainty, 15: 81-97.

Evans, William and John Graham. 1991. Risk reduction or risk compensation? The case of mandatory safety belt use laws. Journal of Risk and Uncertainty, 4(1): 61-73.

Godlonton, Susan, Alister Munthali, and Rebecca Thornton. 2011. Behavioral Response to Information? Circumcision, information, and HIV prevention. BREAD Working Paper No. 313.

Gray, Ronald, Maria Wawer, Ron Brookmeyer, Nelson Sewankambo, David Serwadda, Fred WabwireMangen, Tom Lutalo, Xianbin Li, Thomas van Cott, Thomas Quinn, and the Rakai Project Team. 2001. Probability of HIV-1 transmission per coital act in monogamous, heterosexual, HIV-1-discordant couples in Rakai, Uganda Lancet, 357: 1149-1153.

Gray, Ronald, Godfrey Kigozi, David Serwadda, Frederick Makumbi, StephenWatya, Fred Nalugoda, Noah Kiwanuka, Lawrence Moulton, Mohammad Chaudhary, Michael Chen, Nelson Sewankambo, Fred Wabwire-Mangen, Melanie Bacon, Carolyn Williams, Pius Opendi, Steven Reynolds, Oliver Laeyendecker, Thomas Quinn, Maria Wawer. 2007a. Male circumcision for HIV prevention in men in Rakai, Uganda: A randomised trial. The Lancet, 369(9562): 657 - 666.

Gray, Ronald, Xianbin Li, Godfrey Kigozi, David Serwadda; Fred Nalugoda, Stephen Watya, Steven Reynolds, Maria Wawer. 2007b. The Impact of Male Circumcision on HIV Incidence and Cost per Infection Prevented, a Stochastic Simulation Model from Rakai, Uganda. AIDS 21(April 23): 845-850.

Hallet, Timothy, Ramzi Alsallaq, Jared Baeten, Helen Weiss, Connie Celum, Ronald Gray, and Laith Abu-Raddad. 2011. Will circumcision provide even more protection from HIV to women and men? New estimates of the population impact of circumcision interventions. Sexually Transmitted Infections, 87: 88-93. 
Keeler, Theodore. 1994. Highway safety, economic behavior, and driving environment. The American Economic Review, 84(3): 684-693.

Laumann, Edward, Christopher Masi, Ezra Zuckerman. 1997. Circumcision in the United States: prevalence, prophylactic effects, and sexual practice. Journal of the American Medical Association, 277: 1052-1057.

Mattson, Christine, Robert Bailey, R. Muga, R. Poulussen, and T. Onyango. 2005. Acceptability of male circumcision and predictors of circumcision preference among men and women in Nyanza Province, Kenya. AIDS Care, 17(2): 182-194.

Mattson, Christine, Richard Campbell, Robert Bailer, Kawango Agot, J. O. Ndinya-Achola, Stephen Moses. 2008. Risk compensation is not associated with male circumcision in Kisumu, Kenya: A multi-faceted assessment of men enrolled in a randomized controlled trial. PLoS ONE, 3(6).

Millet, Gregorio, Stephen Flores, Gary Marks, Jennifer Reed, Jeffrey Herbst. 2008. Circumcision status and risk of HIV and sexually transmitted infections among men who have sex with men. Journal of the American Medical Association, 300:1674-1684.

Mehta, Supriya, Stephen Moses, Kawango Agot, Corette Parker, Jeckoniah Ndinya-Achola, Ian Maclean, and Robert Bailey. 2009. Adult Male Circumcision Does Not Reduce the Risk of Incident Neisseria gonorrhoeae, Chlamydia trachomatis, or Trichomonas vaginalis Infection: Results from a Randomized, Controlled Trial in Kenya. The Journal of Infectious Diseases, 200(1): 370-378.

Moses, Stephen, Janet Bradley, Nico Nagelkerke, Allan Ronald, J. O. Ndinya-Achola, and Francis Plummer. 1990. Geographical patterns of male circumcision practices in Africa: Association with HIV seroprevalence. International Journal of Epidemiology, 19(3): 693-697.

Moses, Stephen, Robert Bailey, Allen Ronald. 1998. Male circumcision: assessment of health benefit and risks. Sex Transm Infect, 74: 368-373.

Oster, Emily. 2009. HIV and sexual behavior change: Why not Africa? University of Chicago working paper.

Peltzman, Sam. 1975. The effects of automobile safety regulation. Journal of Political Economy, Vol. 83(4): 677-726.

PlusNews. 2010. Africa: Tracking the male circumcision rollout. March 2, 2010. 
http://www.plusnews.org/report.aspx?ReportID $==88286$

PlusNews. 2011a. Tanzania: Male circumcision campaign targets 2.8 million. February 7, 2011. http://www.plusnews.org/Report.aspx?ReportID=91849

PlusNews. 2011b. New plan to speed up male circumcision. December 6, 2011. http://www.plusnews.org/Report.aspx?Reportid=94404

Richters, Juliet, Anthony Smith, Richard de Visser, Andrew Grulich, Christopher Rissel. 2006. Circumcision in Australia: prevalence and effect on sexual health. Int J STD AIDS,17:547-54.

Tobian, Aaron, David Serwadda, Thomas Quinn, Godfrey Kigozi, Patti Gravitt, Oliver Laeyendecker, Blake Charvat, Victor Ssempijja, Melissa Riedesel, Amy Oliver, Rebecca Nowak, Lawrence Moulton, Michael Chen, Steven Reynolds, Maria Wawer, and Ronald Gray. 2009. Male circumcision for the prevention of HSV-2 and HPV infections and syphilis. New England Journal of Medicine, 360(13):1298-1309.

Wawer, Maria, Ronald Gray, Nelson Sewankambo, David Serwadda, Xianbin Li, Oliver Laeyendecker, Noah Kiwanuka, Godfrey Kigozi, Mohammed Kiddugavu, Thomas Lutalo, Fred Nalugoda, Fred Wabwire-Mangen, Mary Meehan, and Thomas Quinn. 2005. Rates of HIV-1 transmission per coital act, by stage of HIV-1 infection, in Rakai, Uganda. The Journal of Infectious Diseases, 191(1): 1403-1409.

Wawer, Maria, Frederick Makumbi, Godfrey Kigozi, David Serwadda, Stephen Watya, Fred Nalugoda, Dennis Buwembo, Victor Ssempijja, Noah Kiwanuka, Lawrence Moulton, Nelson Sewankambo, Steven Reynolds, Thomas Quinn, Pius Opendi, Boaz Iga, Renee Ridzon, Oliver Laeyendecker, and Ronald Gray. 2009. Circumcision in HIV-infected men and its effect on HIV transmission to female partners in Rakai, Uganda: a randomised controlled trial. The Lancet, 374(9685): 229-237.

Weiss, Helen, Maria Quigley, and Ryan Hayes. Male circumcision and risk of HIV infection in sub-Saharan Africa: a systematic review and meta-analysis. AIDS 2000; 14: 236170.

Weiss, Helen, Sara Thomas, SK Munabi, and Ryan Hayes. 2006. Male circumcision and risk of syphilis, chancroid, and genital herpes: a systematic review and meta-analysis. Sexually Transmitted Infections, 82:101109.

Weiss, Helen, Catherine Hankins, and Kim Dickson. 2009. Male circumcision and risk of HIV 
infection in women: a systematic review and meta-analysis. The Lancet, Infectious Diseases, $9(11) 669-677$.

Westercamp, Matthew, Kawango Agot, Jeckoniah Ndinya-Achola, and Robert Bailey. 2011. Circumcision preference among women and uncircumcised men prior to scale-up of male circumcision for HIV prevention in Kisumu, Kenya. AIDS Care, forthcoming.

Westercamp, Nelli and Robert Bailey. 2007. Acceptability of male circumcision for prevention of HIV/AIDS in Sub-Saharan Africa: A review. AIDS Behavior, 11(3): 341-355.

Winston, Clifford, Vikram Maheshri, and Fred Mannering. 2006. An exploration of the offset hypothesis using disaggregate data: The case of airbags and antilock brakes. Journal of Risk and Uncertainty, 32: 83-99.

WHO. 2007. Male Circumcision, Global Trends and Determinants of Prevalence, Safety, and Acceptability. World Health Organiztion.

WHO. 2009. Progress in Male Circumcision Scale-up: Country Implementation Update. December 2009. World Health Organization. 
Table 1: Descriptive Statistics by Circumcision Assignment at Visit 1

\begin{tabular}{|c|c|c|c|c|c|c|}
\hline \multirow[t]{3}{*}{ Circumcision assignment: } & \multicolumn{2}{|c|}{ circumcised } & \multicolumn{2}{|c|}{ uncircumcised } & \multirow{2}{*}{$\begin{array}{c}\text { difference } \\
\text { in means }\end{array}$} & \multirow[b]{2}{*}{ p-value } \\
\hline & mean & standard deviation & mean & standard deviation & & \\
\hline & $(1)$ & $(2)$ & $(3)$ & $(4)$ & $(5)$ & $(6)$ \\
\hline \multicolumn{7}{|l|}{ Sexual behavior } \\
\hline Number of partners & 5.78 & 3.30 & 5.74 & 3.35 & 0.04 & 0.83 \\
\hline Multiple partners & 0.95 & 0.22 & 0.94 & 0.23 & 0.01 & 0.44 \\
\hline Always use condom & 0.61 & 0.43 & 0.60 & 0.43 & 0.01 & 0.77 \\
\hline Used condom last time & 0.66 & 0.41 & 0.67 & 0.41 & -0.01 & 0.81 \\
\hline \multicolumn{7}{|l|}{ Other characteristics } \\
\hline Age & 20.44 & 1.60 & 20.48 & 1.66 & -0.04 & 0.64 \\
\hline Believe circumcision is effective & 0.57 & 0.49 & 0.56 & 0.50 & 0.01 & 0.59 \\
\hline Employed & 0.50 & 0.50 & 0.48 & 0.50 & 0.02 & 0.36 \\
\hline Married/cohabit & 0.068 & 0.25 & 0.073 & 0.26 & -0.005 & 0.73 \\
\hline Income (average monthly) & 2.60 & 2.91 & 2.56 & 3.89 & 0.04 & 0.84 \\
\hline Years of schooling & 10.90 & 2.44 & 10.98 & 2.39 & -0.08 & 0.59 \\
\hline Observations & 616 & 616 & 684 & 684 & 1,300 & 1,300 \\
\hline
\end{tabular}

Notes: Circumcised is an indicator variable equal to one if the individual was assigned to receive circumcision. Believe is an indicator variable

equal to one if the individual reported believing circumcision reduces the likelihood acquiring HIV. Age measures the respondent's age in years.

Married/cohabit is an indicator variable. Employed is an indicator variable. Income measures average monthly income in '000's of Kenyan

schillings. Number of partners measures the number of sexual partners the respondent had thus far during their lifetime. Multiple partners is an indicator variable equal to one if the individual had more than one sexual partner thus far during their lifetime. Always use condom measures the fraction of partners with whom the respondent reported always using a condom. Used condom last time measures the fraction of partners with whom the respondent reported using a condom during their last sexual encounter. 
Table 2: Descriptive Statistics by Belief at Visit 1

\begin{tabular}{|c|c|c|c|c|c|c|}
\hline \multirow[t]{3}{*}{ Belief at Visit 1: } & \multicolumn{2}{|c|}{ believe } & \multicolumn{2}{|c|}{ not believe } & \multirow{3}{*}{$\begin{array}{c}\text { difference } \\
\text { in means } \\
(5)\end{array}$} & \multirow{3}{*}{$\frac{\mathrm{p} \text {-value }}{(6)}$} \\
\hline & mean & standard deviation & mean & standard deviation & & \\
\hline & $(1)$ & (2) & $(3)$ & (4) & & \\
\hline \multicolumn{7}{|l|}{ Sexual behavior } \\
\hline Number of partners & 5.75 & 3.24 & 5.77 & 3.44 & -0.02 & 0.91 \\
\hline Multiple partners & 0.96 & 0.20 & 0.93 & 0.25 & 0.03 & 0.03 \\
\hline Always use condom & 0.61 & 0.43 & 0.60 & 0.43 & 0.01 & 0.69 \\
\hline Used condom last time & 0.67 & 0.42 & 0.67 & 0.41 & 0.00 & 0.94 \\
\hline \multicolumn{7}{|l|}{ Other characteristics } \\
\hline Age & 20.34 & 1.65 & 20.61 & 1.60 & -0.27 & 0.01 \\
\hline Circumcised & 0.48 & 0.50 & 0.47 & 0.50 & 0.01 & 0.69 \\
\hline Employed & 0.50 & 0.50 & 0.48 & 0.50 & 0.02 & 0.39 \\
\hline Married/cohabit & 0.07 & 0.25 & 0.078 & 0.27 & -0.013 & 0.35 \\
\hline Income (average monthly) & 2.56 & 3.99 & 2.56 & 2.99 & 0.00 & 0.83 \\
\hline Years of schooling & 10.88 & 2.38 & 11.02 & 2.46 & -0.14 & 0.31 \\
\hline Observations & 739 & 739 & 561 & 561 & 1,300 & 1,300 \\
\hline
\end{tabular}

Notes: Circumcised is an indicator variable equal to one if the individual was randomly assigned to receive circumcision. Believe is an indicator

variable equal to one if the individual reported believing circumcision reduces the likelihood acquiring HIV. Age measures the respondent's age in years. Married/cohabit is an indicator variable. Employed is an indicator variable. Income measures average monthly income in '000's of Kenyan schillings. Number of partners measures the number of sexual partners the respondent had thus far during their lifetime. Multiple partners is an indicator variable equal to one if the individual had more than one sexual partner thus far during their lifetime. Always use condom measures the fraction of partners with whom the respondent reported always using a condom. Used condom last time measures the fraction of partners with whom the respondent reported using a condom during their last sexual encounter. 
Table 3: Descriptive Statistics by Interaction of Circumcised and Belief at Visit 1

\begin{tabular}{|c|c|c|c|c|c|c|c|}
\hline \multirow{3}{*}{$\begin{array}{l}\text { Belief at Visit 1: } \\
\text { Circumcision assignment: }\end{array}$} & \multicolumn{2}{|c|}{ believe } & \multirow{3}{*}{$\frac{\text { difference }}{(3)}$} & \multicolumn{2}{|c|}{ not believe } & \multirow{3}{*}{$\frac{\text { difference }}{(6)}$} & \multirow{3}{*}{$\begin{array}{l}\begin{array}{r}\text { difference in } \\
\text { differences }\end{array} \\
(7)\end{array}$} \\
\hline & circumcised & uncircumcised & & circumcised & uncircumcised & & \\
\hline & $(1)$ & $(2)$ & & $(4)$ & $(5)$ & & \\
\hline \multicolumn{8}{|l|}{ Sexual behavior } \\
\hline Number of partners & $\begin{array}{c}5.87 \\
(3.19)\end{array}$ & $\begin{array}{c}5.64 \\
(3.28)\end{array}$ & $\begin{array}{c}0.23 \\
(\mathrm{p}-\mathrm{val}=0.33)\end{array}$ & $\begin{array}{l}5.65 \\
(3.45)\end{array}$ & $\begin{array}{l}5.88 \\
(3.44)\end{array}$ & $\begin{array}{c}-0.23 \\
(p-v a l=0.44)\end{array}$ & $\begin{array}{c}0.46 \\
(\mathrm{p}-\mathrm{val}=0.22)\end{array}$ \\
\hline Multiple partners & $\begin{array}{c}0.97 \\
(0.26)\end{array}$ & $\begin{array}{c}0.95 \\
(0.22)\end{array}$ & $\begin{array}{c}0.02 \\
(\mathrm{p}-\mathrm{val}=0.16)\end{array}$ & $\begin{array}{c}0.93 \\
(0.26)\end{array}$ & $\begin{array}{c}0.93 \\
(0.25)\end{array}$ & $\begin{array}{c}0.00 \\
(\mathrm{p}-\mathrm{val}=0.79)\end{array}$ & $\begin{array}{c}0.02 \\
(\mathrm{p}-\mathrm{val}=0.31)\end{array}$ \\
\hline Always use condom & $\begin{array}{c}0.62 \\
(0.43)\end{array}$ & $\begin{array}{c}0.60 \\
(0.43)\end{array}$ & $\begin{array}{c}0.02 \\
(\mathrm{p}-\mathrm{val}=0.45)\end{array}$ & $\begin{array}{c}0.59 \\
(0.43)\end{array}$ & $\begin{array}{c}0.61 \\
(0.43)\end{array}$ & $\begin{array}{c}0.01 \\
(\mathrm{p}-\mathrm{val}=0.75)\end{array}$ & $\begin{array}{c}0.01 \\
(\mathrm{p}-\mathrm{val}=0.46)\end{array}$ \\
\hline Used condom last time & $\begin{array}{c}0.68 \\
(0.40)\end{array}$ & $\begin{array}{c}0.66 \\
(0.42)\end{array}$ & $\begin{array}{c}0.02 \\
(\mathrm{p}-\mathrm{val}=0.61)\end{array}$ & $\begin{array}{c}0.65 \\
(0.42)\end{array}$ & $\begin{array}{c}0.68 \\
(0.41)\end{array}$ & $\begin{array}{c}-0.03 \\
(p-v a l=0.41)\end{array}$ & $\begin{array}{c}0.05 \\
(\mathrm{p}-\mathrm{val}=0.34)\end{array}$ \\
\hline \multicolumn{8}{|l|}{ Other characteristics } \\
\hline Age & $\begin{array}{l}20.36 \\
(1.61)\end{array}$ & $\begin{array}{l}20.31 \\
(1.68)\end{array}$ & $\begin{array}{c}0.05 \\
(p-v a l=0.68)\end{array}$ & $\begin{array}{l}20.53 \\
(1.58)\end{array}$ & $\begin{array}{l}20.67 \\
(1.61)\end{array}$ & $\begin{array}{c}-0.14 \\
(p-v a l=0.30)\end{array}$ & $\begin{array}{c}0.19 \\
(\mathrm{p}-\mathrm{val}=0.29)\end{array}$ \\
\hline Employed & $\begin{array}{c}0.50 \\
(0.50)\end{array}$ & $\begin{array}{c}0.50 \\
(0.50)\end{array}$ & $\begin{array}{c}0.00 \\
(\mathrm{p}-\mathrm{val}=0.92)\end{array}$ & $\begin{array}{c}0.51 \\
(0.50)\end{array}$ & $\begin{array}{c}0.45 \\
(0.50)\end{array}$ & $\begin{array}{c}0.06 \\
(\mathrm{p}-\mathrm{val}=0.13)\end{array}$ & $\begin{array}{c}-0.06 \\
(p-v a l=0.23)\end{array}$ \\
\hline Married/cohabit & $\begin{array}{l}0.056 \\
(0.23)\end{array}$ & $\begin{array}{l}0.072 \\
(0.26)\end{array}$ & $\begin{array}{c}-0.016 \\
(p-v a l=0.37)\end{array}$ & $\begin{array}{l}0.084 \\
(0.28)\end{array}$ & $\begin{array}{l}0.074 \\
(0.26)\end{array}$ & $\begin{array}{c}0.010 \\
(p-v a l=0.65)\end{array}$ & $\begin{array}{c}-0.026 \\
(p-v a l=0.36)\end{array}$ \\
\hline Income (average monthly) & $\begin{array}{c}2.69 \\
(3.35)\end{array}$ & $\begin{array}{c}2.44 \\
(2.62)\end{array}$ & $\begin{array}{c}0.25 \\
(p-v a l=0.26)\end{array}$ & $\begin{array}{l}2.48 \\
(2.18)\end{array}$ & $\begin{array}{c}2.70 \\
(0.51)\end{array}$ & $\begin{array}{c}-0.22 \\
(p-v a l=0.51)\end{array}$ & $\begin{array}{c}0.47 \\
(\mathrm{p}-\mathrm{val}=0.23)\end{array}$ \\
\hline Years of schooling & $\begin{array}{l}10.92 \\
(2.36)\end{array}$ & $\begin{array}{l}10.86 \\
(2.39)\end{array}$ & $\begin{array}{c}0.06 \\
(\mathrm{p}-\mathrm{val}=0.74)\end{array}$ & $\begin{array}{l}10.89 \\
(2.54)\end{array}$ & $\begin{array}{l}11.14 \\
(2.39)\end{array}$ & $\begin{array}{c}-0.25 \\
(\mathrm{p}-\mathrm{val}=0.22)\end{array}$ & $\begin{array}{c}0.31 \\
(p-v a l=0.24)\end{array}$ \\
\hline Observations & 354 & 385 & 789 & 262 & 299 & 561 & 1,300 \\
\hline
\end{tabular}

Notes: Entries are sample means. Standard deviations in parathenses unless noted otherwise. Circumcised is an indicator variable equal to one if the individual was randomly assigned to receive circumcision. Believe is an indicator variable equal to one if, at the beginning of the reference period over which sexual behavior was measured, the individual reported believing circumcision reduces the likelihood acquiring HIV. Number of partners measures the number of sexual partners the respondent had thus far during their lifetime. Multiple partners is an indicator variable equal to one if the individual had more than one sexual partner thus far during their lifetime. Always use condom measures the fraction of partners with whom the respondent reported always using a condom. Used condom last time measures the fraction of partners with whom the respondent reported using a condom during their last sexual encounter. 
Table 4: Sexual Behavior at Follow-Up Visits by Interaction of Circumcision Status and Beliefs

\begin{tabular}{|c|c|c|c|c|c|c|c|}
\hline \multirow{3}{*}{$\begin{array}{l}\text { Belief at beginning of reference period: } \\
\text { Circumcision assignment: }\end{array}$} & \multicolumn{2}{|c|}{ believe } & \multirow{3}{*}{$\frac{\text { difference }}{(3)}$} & \multicolumn{2}{|c|}{ not believe } & \multirow{3}{*}{$\frac{\text { difference }}{(6)}$} & \multirow{3}{*}{$\begin{array}{c}\text { difference in } \\
\text { differences } \\
(7)\end{array}$} \\
\hline & circumcised & uncircumcised & & circumcised & uncircumcised & & \\
\hline & $(1)$ & (2) & & $(4)$ & $(5)$ & & \\
\hline \multicolumn{8}{|l|}{ Panel A: Visit 2} \\
\hline Number of partners & $\begin{array}{c}1.49 \\
(1.26)\end{array}$ & $\begin{array}{l}1.58 \\
(1.46)\end{array}$ & $\begin{array}{c}-0.09 \\
(p-v a l=0.46)\end{array}$ & $\begin{array}{c}1.64 \\
(1.53)\end{array}$ & $\begin{array}{c}1.40 \\
(1.24)\end{array}$ & $\begin{array}{c}0.24 \\
(\mathrm{p}-\mathrm{val}=0.07)\end{array}$ & $\begin{array}{c}-0.33 \\
(\mathrm{p}-\mathrm{val}=0.07)\end{array}$ \\
\hline Multiple partners & $\begin{array}{c}0.36 \\
(0.48)\end{array}$ & $\begin{array}{c}0.40 \\
(0.49)\end{array}$ & $\begin{array}{c}-0.04 \\
(p-v a l=0.36)\end{array}$ & $\begin{array}{c}0.43 \\
(0.50)\end{array}$ & $\begin{array}{c}0.34 \\
(0.48)\end{array}$ & $\begin{array}{c}0.09 \\
(\mathrm{p}-\mathrm{val}=0.06)\end{array}$ & $\begin{array}{c}-0.13 \\
(p-v a l=0.04)\end{array}$ \\
\hline Always use condom & $\begin{array}{c}0.60 \\
(0.48)\end{array}$ & $\begin{array}{c}0.64 \\
(0.46)\end{array}$ & $\begin{array}{c}-0.04 \\
(p-v a l=0.33)\end{array}$ & $\begin{array}{c}0.61 \\
(0.47)\end{array}$ & $\begin{array}{c}0.62 \\
(0.47)\end{array}$ & $\begin{array}{c}-0.01 \\
(\mathrm{p}-\mathrm{val}=0.71)\end{array}$ & $\begin{array}{c}-0.03 \\
(\mathrm{p}-\mathrm{val}=0.71)\end{array}$ \\
\hline Used condom last time & $\begin{array}{c}0.66 \\
(0.45)\end{array}$ & $\begin{array}{c}0.70 \\
(0.44)\end{array}$ & $\begin{array}{c}-0.04 \\
(p-v a l=0.30)\end{array}$ & $\begin{array}{c}0.68 \\
(0.45)\end{array}$ & $\begin{array}{c}0.70 \\
(0.45)\end{array}$ & $\begin{array}{c}-0.02 \\
(p-v a l=0.71)\end{array}$ & $\begin{array}{c}-0.02 \\
(\mathrm{p}-\mathrm{val}=0.68)\end{array}$ \\
\hline Observations & 265 & 288 & 553 & 204 & 241 & 445 & 998 \\
\hline \multicolumn{8}{|l|}{ Panel B: Visit 3} \\
\hline Number of partners & $\begin{array}{c}1.38 \\
(1.20)\end{array}$ & $\begin{array}{c}1.58 \\
(1.55)\end{array}$ & $\begin{array}{c}-0.20 \\
(p-v a l=0.07)\end{array}$ & $\begin{array}{c}1.66 \\
(1.25)\end{array}$ & $\begin{array}{c}1.33 \\
(1.38)\end{array}$ & $\begin{array}{c}0.33 \\
(\mathrm{p}-\mathrm{val}=0.04)\end{array}$ & $\begin{array}{c}-0.53 \\
(\mathrm{p}-\mathrm{val}=0.00)\end{array}$ \\
\hline Multiple partners & $\begin{array}{c}0.34 \\
(0.47)\end{array}$ & $\begin{array}{c}0.39 \\
(0.49)\end{array}$ & $\begin{array}{c}-0.05 \\
(p-v a l=0.19)\end{array}$ & $\begin{array}{c}0.46 \\
(0.50)\end{array}$ & $\begin{array}{c}0.33 \\
(0.47)\end{array}$ & $\begin{array}{c}0.13 \\
(\mathrm{p}-\mathrm{val}=0.03)\end{array}$ & $\begin{array}{c}-0.18 \\
(\mathrm{p}-\mathrm{val}=0.01)\end{array}$ \\
\hline Always use condom & $\begin{array}{c}0.60 \\
(0.47)\end{array}$ & $\begin{array}{c}0.63 \\
(0.47)\end{array}$ & $\begin{array}{c}-0.03 \\
(p-v a l=0.39)\end{array}$ & $\begin{array}{c}0.56 \\
(0.48)\end{array}$ & $\begin{array}{c}0.71 \\
(0.43)\end{array}$ & $\begin{array}{c}-0.15 \\
(p-v a l=0.01)\end{array}$ & $\begin{array}{c}0.12 \\
(\mathrm{p}-\mathrm{val}=0.09)\end{array}$ \\
\hline Used condom last time & $\begin{array}{c}0.66 \\
(0.45)\end{array}$ & $\begin{array}{c}0.67 \\
(0.46)\end{array}$ & $\begin{array}{c}-0.01 \\
(p-v a l=0.89)\end{array}$ & $\begin{array}{c}0.62 \\
(0.47)\end{array}$ & $\begin{array}{c}0.76 \\
(0.41)\end{array}$ & $\begin{array}{c}-0.14 \\
(p-v a l=0.01)\end{array}$ & $\begin{array}{c}0.13 \\
(\mathrm{p}-\mathrm{val}=0.04)\end{array}$ \\
\hline Observations & 280 & 322 & 602 & 130 & 135 & 265 & 867 \\
\hline
\end{tabular}

Notes: Entries are sample means. Standard deviations in parathenses unless noted otherwise. Circumcised is an indicator variable equal to one if the individual was randomly assigned to receive circumcision. Believe is an indicator variable equal to one if, at the beginning of the reference period over which sexual behavior was measured, the individual reported believing circumcision reduces the likelihood acquiring HIV. Number of partners measures the number of sexual partners the repsondent had during the six month period prior to the interview data. Multiple partners is an indicator variable equal to one if the individual had more than one sexual partner during the six month period prior to the interview date. Always use condom measures the fraction of partners with whom the respondent reported always using a condom. Used condom last time measures the fraction of partners with whom the respondent reported using a condom during their last sexual encounter. 
Table 5: Effect of Circumcision on Risky Sexual Behavior

\begin{tabular}{|c|c|c|c|c|c|c|c|c|}
\hline \multirow{3}{*}{$\begin{array}{l}\text { Visit: } \\
\text { Dependent variable: }\end{array}$} & \multicolumn{4}{|c|}{ visit 2} & \multicolumn{4}{|c|}{ visit 3} \\
\hline & $\begin{array}{c}\text { number of } \\
\text { partners }\end{array}$ & $\begin{array}{l}\text { multiple } \\
\text { partners }\end{array}$ & $\begin{array}{l}\text { always use } \\
\text { condom }\end{array}$ & $\begin{array}{c}\text { used condom } \\
\text { last time } \\
\end{array}$ & $\begin{array}{c}\text { number of } \\
\text { partners }\end{array}$ & $\begin{array}{l}\text { multiple } \\
\text { partners }\end{array}$ & $\begin{array}{l}\text { always use } \\
\text { condom } \\
\end{array}$ & $\begin{array}{l}\text { used condom } \\
\text { last time }\end{array}$ \\
\hline & $(1)$ & $(2)$ & $(3)$ & $(4)$ & $(5)$ & $(6)$ & $(7)$ & $(8)$ \\
\hline Circumcised & $\begin{array}{l}0.237 * \\
(0.134)\end{array}$ & $\begin{array}{l}0.090^{*} \\
(0.046)\end{array}$ & $\begin{array}{l}-0.017 \\
(0.045)\end{array}$ & $\begin{array}{l}-0.016 \\
(0.043)\end{array}$ & $\begin{array}{l}0.328 * * \\
(0.162)\end{array}$ & $\begin{array}{l}0.128 * * \\
(0.060)\end{array}$ & $\begin{array}{c}-0.149 * * * \\
(0.056)\end{array}$ & $\begin{array}{c}-0.145 * * * \\
(0.054)\end{array}$ \\
\hline Believe & $\begin{array}{c}0.181 \\
(0.117)\end{array}$ & $\begin{array}{c}0.06 \\
(0.042)\end{array}$ & $\begin{array}{c}0.018 \\
(0.041)\end{array}$ & $\begin{array}{c}0.000 \\
(0.039)\end{array}$ & $\begin{array}{l}0.251 * \\
(0.147)\end{array}$ & $\begin{array}{c}0.058 \\
(0.049)\end{array}$ & $\begin{array}{l}-0.082 * \\
(0.046)\end{array}$ & $\begin{array}{c}-0.097 * * \\
(0.043)\end{array}$ \\
\hline Circumcised X Believe & $\begin{array}{l}-0.324^{*} \\
(0.177)\end{array}$ & $\begin{array}{c}-0.129 * * \\
(0.062)\end{array}$ & $\begin{array}{l}-0.022 \\
(0.060)\end{array}$ & $\begin{array}{l}-0.024 \\
(0.058)\end{array}$ & $\begin{array}{c}-0.537 * * * \\
(0.197)\end{array}$ & $\begin{array}{c}-0.180 * * \\
(0.072)\end{array}$ & $\begin{array}{l}0.116^{*} \\
(0.068)\end{array}$ & $\begin{array}{c}0.140 * * \\
(0.066)\end{array}$ \\
\hline $\begin{array}{l}P>F(\text { Circumcised }+ \\
\text { Circumcised X Believe }=0)\end{array}$ & 0.442 & 0.328 & 0.318 & 0.289 & 0.064 & 0.186 & 0.388 & 0.890 \\
\hline Observations & 998 & 998 & 998 & 998 & 867 & 867 & 867 & 867 \\
\hline
\end{tabular}

Notes: Circumcised is an indicator variable equal to one if the individual was randomly assigned to receive circumcision. Believe is an indicator variable equal to one if at the beginning of the six month interval over which sexual behavior was recorded the individual reported believing that circumcision reduces the likelihood acquiring HIV. Number of partners measures the number of sexual partners the respondent had during the six month period prior to the interview data. Multiple partners is an indicator variable equal to one if the individual had more than one sexual partner during the six month period prior to the interview date. Always use condom measures the fraction of partners with whom the respondent reported always using a condom. Used condom last time measures the fraction of partners with whom the respondent reported using a condom during their last sexual encounter. Visit 2 refers to the six month follow-up after the baseline interview. Visit 3 refers to the twelve month follow-up after the baseline interview. Heteroskedasticity-robust standard errors reported in parentheses.

$* * *$ Significant at the $1 \%$ level, **Significant at $5 \%$ level, $*$ Significant at $10 \%$ level. 
Table 6: Placebo Test Using Baseline Risky Sexual Behavior

\begin{tabular}{|c|c|c|c|c|c|c|c|c|}
\hline \multirow{4}{*}{$\begin{array}{l}\text { Sample: } \\
\text { Visit: } \\
\text { Dependent variable: }\end{array}$} & \multicolumn{4}{|c|}{ full sample } & \multicolumn{4}{|c|}{ sub-sample successfully interviewed at visit 2} \\
\hline & \multicolumn{4}{|c|}{ visit 1} & \multicolumn{4}{|c|}{ visit 1} \\
\hline & $\begin{array}{c}\text { number of } \\
\text { partners }\end{array}$ & $\begin{array}{l}\text { multiple } \\
\text { partners }\end{array}$ & $\begin{array}{l}\text { always use } \\
\text { condom }\end{array}$ & $\begin{array}{l}\text { used condom } \\
\text { last time }\end{array}$ & $\begin{array}{c}\text { number of } \\
\text { partners }\end{array}$ & $\begin{array}{l}\text { multiple } \\
\text { partners }\end{array}$ & $\begin{array}{l}\text { always use } \\
\text { condom }\end{array}$ & $\begin{array}{l}\text { used condom } \\
\text { last time }\end{array}$ \\
\hline & $(1)$ & $(2)$ & $(3)$ & $(4)$ & $(5)$ & $(6)$ & $(7)$ & $\begin{array}{c}(8) \\
\end{array}$ \\
\hline Circumcised & $\begin{array}{l}-0.224 \\
(0.291)\end{array}$ & $\begin{array}{l}-0.006 \\
(0.022)\end{array}$ & $\begin{array}{l}-0.012 \\
(0.036)\end{array}$ & $\begin{array}{l}-0.029 \\
(0.035)\end{array}$ & $\begin{array}{l}-0.072 \\
(0.338)\end{array}$ & $\begin{array}{c}0.003 \\
(0.024)\end{array}$ & $\begin{array}{l}-0.004 \\
(0.040)\end{array}$ & $\begin{array}{l}-0.023 \\
(0.039)\end{array}$ \\
\hline Believe & $\begin{array}{l}-0.237 \\
(0.260)\end{array}$ & $\begin{array}{c}0.015 \\
(0.018)\end{array}$ & $\begin{array}{l}-0.007 \\
(0.033)\end{array}$ & $\begin{array}{l}-0.019 \\
(0.032)\end{array}$ & $\begin{array}{l}-0.158 \\
(0.299)\end{array}$ & $\begin{array}{c}0.016 \\
(0.021)\end{array}$ & $\begin{array}{l}-0.031 \\
(0.037)\end{array}$ & $\begin{array}{l}-0.037 \\
(0.036)\end{array}$ \\
\hline Circumcised X Believe & $\begin{array}{c}0.458 \\
(0.376)\end{array}$ & $\begin{array}{c}0.027 \\
(0.026)\end{array}$ & $\begin{array}{c}0.036 \\
(0.048)\end{array}$ & $\begin{array}{c}0.044 \\
(0.046)\end{array}$ & $\begin{array}{c}0.242 \\
(0.436)\end{array}$ & $\begin{array}{c}0.019 \\
(0.030)\end{array}$ & $\begin{array}{c}0.032 \\
(0.055)\end{array}$ & $\begin{array}{c}0.032 \\
(0.053)\end{array}$ \\
\hline $\begin{array}{l}\mathrm{P}>\mathrm{F}(\text { Circumcised }+ \\
\text { Circumcised X Believe }=0)\end{array}$ & 0.326 & 0.154 & 0.446 & 0.612 & 0.549 & 0.225 & 0.437 & 0.810 \\
\hline Observations & 1,300 & 1,300 & 1,300 & 1,300 & 998 & 998 & 998 & 998 \\
\hline
\end{tabular}

Notes: Circumcised is an indicator variable equal to one if the individual was randomly assigned to receive circumcision. Believe is an indicator variable

equal to one if at baseline the individual reported believing that circumcision reduces the likelihood acquiring HIV. Number of partners measures the

number of sexual partners the respondent had thus far during their lifetime. Multiple partners is an indicator variable equal to one if the individual had more

than one sexual partner thus far during their lifetime. Always use condom measures the fraction of partners with whom the respondent reported always

using a condom. Used condom last time measures the fraction of partners with whom the respondent reported using a condom during their last sexual

encounter. Visit 1 refers to the baseline interview. Heteroskedasticity-robust standard errors reported in parentheses.

***Significant at the $1 \%$ level, **Significant at 5\% level, *Significant at $10 \%$ level. 
Table 7: Robustness to Additional Controls

\begin{tabular}{|c|c|c|c|c|c|c|c|c|}
\hline \multirow{2}{*}{$\begin{array}{l}\text { Visit: } \\
\text { Dependent variable: }\end{array}$} & \multicolumn{4}{|c|}{ visit 2} & \multicolumn{4}{|c|}{ visit 3} \\
\hline & $\begin{array}{c}\begin{array}{c}\text { number of } \\
\text { partners }\end{array} \\
(1)\end{array}$ & $\begin{array}{c}\begin{array}{c}\text { multiple } \\
\text { partners }\end{array} \\
(2)\end{array}$ & $\begin{array}{l}\text { always use } \\
\text { condom } \\
(3)\end{array}$ & $\begin{array}{c}\text { used condom } \\
\text { last time } \\
(4)\end{array}$ & $\begin{array}{c}\begin{array}{c}\text { number of } \\
\text { partners }\end{array} \\
(5)\end{array}$ & $\begin{array}{c}\begin{array}{c}\text { multiple } \\
\text { partners }\end{array} \\
(6)\end{array}$ & $\begin{array}{l}\text { always use } \\
\text { condom } \\
(7)\end{array}$ & $\begin{array}{l}\text { used condom } \\
\text { last time } \\
(8)\end{array}$ \\
\hline Circumcised & $\begin{array}{l}0.233^{*} \\
(0.133)\end{array}$ & $\begin{array}{l}0.086^{*} \\
(0.047)\end{array}$ & $\begin{array}{l}-0.008 \\
(0.043)\end{array}$ & $\begin{array}{l}-0.009 \\
(0.040)\end{array}$ & $\begin{array}{l}0.315^{*} \\
(0.162)\end{array}$ & $\begin{array}{c}0.130^{* *} \\
(0.059)\end{array}$ & $\begin{array}{c}-0.129 * * \\
(0.054)\end{array}$ & $\begin{array}{c}-0.124^{* *} \\
(0.052)\end{array}$ \\
\hline Believe & $\begin{array}{c}0.170 \\
(0.122)\end{array}$ & $\begin{array}{c}0.049 \\
(0.043)\end{array}$ & $\begin{array}{c}0.029 \\
(0.040)\end{array}$ & $\begin{array}{c}0.010 \\
(0.038)\end{array}$ & $\begin{array}{c}0.220 \\
(0.149)\end{array}$ & $\begin{array}{c}0.055 \\
(0.049)\end{array}$ & $\begin{array}{l}-0.044 \\
(0.043)\end{array}$ & $\begin{array}{l}-0.058 \\
(0.040)\end{array}$ \\
\hline Circumcised X Believe & $\begin{array}{l}-0.312^{*} \\
(0.177)\end{array}$ & $\begin{array}{c}-0.123 * * \\
(0.062)\end{array}$ & $\begin{array}{l}-0.044 \\
(0.058)\end{array}$ & $\begin{array}{l}-0.044 \\
(0.055)\end{array}$ & $\begin{array}{c}-0.513 * * * \\
(0.198)\end{array}$ & $\begin{array}{c}-0.180 * * \\
(0.071)\end{array}$ & $\begin{array}{c}0.085 \\
(0.065)\end{array}$ & $\begin{array}{l}0.107^{*} \\
(0.062)\end{array}$ \\
\hline Age & $\begin{array}{c}0.015 \\
(0.027)\end{array}$ & $\begin{array}{l}-0.001 \\
(0.010)\end{array}$ & $\begin{array}{c}-0.002 \\
(0.009)\end{array}$ & $\begin{array}{l}-0.001 \\
(0.009)\end{array}$ & $\begin{array}{c}0.022 \\
(0.030)\end{array}$ & $\begin{array}{c}0.009 \\
(0.011)\end{array}$ & $\begin{array}{c}0.019 * * \\
(0.009)\end{array}$ & $\begin{array}{c}0.019 * * \\
(0.009)\end{array}$ \\
\hline Married/cohabit & $\begin{array}{c}0.070 \\
(0.209)\end{array}$ & $\begin{array}{l}-0.079 \\
(0.059)\end{array}$ & $\begin{array}{c}-0.286^{* * *} \\
(0.053)\end{array}$ & $\begin{array}{c}-0.310^{* * *} \\
(0.055)\end{array}$ & $\begin{array}{c}0.138 \\
(0.192)\end{array}$ & $\begin{array}{l}-0.105^{*} \\
(0.054)\end{array}$ & $\begin{array}{c}-0.470 * * * \\
(0.043)\end{array}$ & $\begin{array}{c}-0.503^{* * *} \\
(0.044)\end{array}$ \\
\hline Years of schooling & $\begin{array}{l}-0.016 \\
(0.018)\end{array}$ & $\begin{array}{c}0.002 \\
(0.007)\end{array}$ & $\begin{array}{c}0.025^{* * *} \\
(0.007)\end{array}$ & $\begin{array}{c}0.025^{* * *} \\
(0.006)\end{array}$ & $\begin{array}{l}-0.011 \\
(0.021)\end{array}$ & $\begin{array}{l}-0.005 \\
(0.007)\end{array}$ & $\begin{array}{c}0.018 * * * \\
(0.007)\end{array}$ & $\begin{array}{c}0.017 * * * \\
(0.006)\end{array}$ \\
\hline Employed & $\begin{array}{l}0.167 * \\
(0.101)\end{array}$ & $\begin{array}{c}0.050 \\
(0.035)\end{array}$ & $\begin{array}{c}-0.097 * * * \\
(0.032)\end{array}$ & $\begin{array}{c}-0.091 * * * \\
(0.031)\end{array}$ & $\begin{array}{l}0.162^{*} \\
(0.098)\end{array}$ & $\begin{array}{c}0.037 \\
(0.036)\end{array}$ & $\begin{array}{c}-0.070 * * \\
(0.032)\end{array}$ & $\begin{array}{c}-0.074 * * \\
(0.030)\end{array}$ \\
\hline Income & $\begin{array}{c}0.021 \\
(0.013)\end{array}$ & $\begin{array}{c}0.006 \\
(0.006)\end{array}$ & $\begin{array}{l}-0.006 \\
(0.004)\end{array}$ & $\begin{array}{c}-0.008^{* *} \\
(0.004)\end{array}$ & $\begin{array}{c}0.013 \\
(0.013)\end{array}$ & $\begin{array}{c}0.004 \\
(0.005)\end{array}$ & $\begin{array}{c}-0.008^{* * *} \\
(0.003)\end{array}$ & $\begin{array}{c}-0.008^{* * *} \\
(0.003)\end{array}$ \\
\hline Observations & 998 & 998 & 998 & 998 & 867 & 867 & 867 & 867 \\
\hline
\end{tabular}

Notes: Circumcised is an indicator variable equal to one if the individual was randomly assigned to receive circumcision.

Believe is an indicator variable equal to one if at the beginning of the six month interval over which sexual behavior was recorded the individual reported believing that circumcision reduces the likelihood acquiring HIV. Age measures the respondents age in years. Married/cohabit is an indicator variable. Employed is an indicator variable. Income measures average monthly income in '000's of Kenyan schillings. Number of partners measures the number of sexual partners the repsondent had during the six month period prior to the interview data. Multiple partners is an indicator variable equal to one if the individual had more than one sexual partner during the six month period prior to the interview date. Always use condom measures the fraction of partners with whom the respondent reported always using a condom. Used condom last time measures the fraction of partners with whom the respondent reported using a condom during their last sexual encounter. Visit 2 refers to the six month follow-up after the baseline interview. Visit 3 refers to the twelve month follow-up after the baseline interview. Heteroskedasticity-robust standard errors reported in parentheses.

***Significant at the $1 \%$ level, $* *$ Significant at $5 \%$ level, *Significant at $10 \%$ level. 
Table 8: Correlates of Belief in Prevention Benefit of Circumcision

\begin{tabular}{|c|c|c|c|}
\hline \multirow{3}{*}{$\begin{array}{l}\text { Dependent variable: } \\
\text { Visit: }\end{array}$} & \multicolumn{3}{|c|}{ believe } \\
\hline & visit 1 & visit 2 & visit 3 \\
\hline & (1) & $(2)$ & (3) \\
\hline \multirow[t]{2}{*}{ Circumcised } & 0.01 & -0.022 & -0.008 \\
\hline & $(0.027)$ & $(0.029)$ & $(0.027)$ \\
\hline \multirow[t]{2}{*}{ Age } & $-0.025^{* * *}$ & $-0.021 * *$ & -0.009 \\
\hline & $(0.009)$ & $(0.010)$ & $(0.009)$ \\
\hline \multirow[t]{2}{*}{ Married/cohabit } & -0.040 & 0.036 & -0.052 \\
\hline & $(0.056)$ & $(0.047)$ & $(0.044)$ \\
\hline \multirow[t]{2}{*}{ Years of schooling } & -0.002 & -0.007 & 0.000 \\
\hline & $(0.006)$ & $(0.006)$ & $(0.006)$ \\
\hline \multirow[t]{2}{*}{ Employed } & 0.040 & 0.034 & 0.024 \\
\hline & $(0.030)$ & $(0.031)$ & $(0.030)$ \\
\hline \multirow[t]{2}{*}{ Income } & 0.000 & $0.007 * *$ & 0.002 \\
\hline & $(0.004)$ & $(0.003)$ & $(0.003)$ \\
\hline Observations & 1,300 & 998 & 867 \\
\hline
\end{tabular}

Notes: Circumcised is an indicator variable equal to one if the individual was randomly assigned to receive circumcision.

Believe is an indicator variable equal to one if at the beginning of the six month interval over which sexual behavior was recorded the individual reported believing that circumcision reduces the likelihood acquiring HIV. Age measures the respondents age in years. Married/cohabit is an indicator variable. Employed is an indicator variable. Income measures average monthly income in '000's of Kenyan schillings. Visit 1 refers to baseline interview. Visit 2 refers to the six month follow-up after the baseline interview. Visit 3 refers to the twelve month follow-up after the baseline interview. Heteroskedasticity-robust standard errors reported in parentheses.

$* * *$ Significant at the $1 \%$ level, **Significant at $5 \%$ level, * Significant at $10 \%$ level. 
Table 9: Robustness Checks for Partnerships at Visit 2 to Additional Interactions

\begin{tabular}{|c|c|c|c|c|c|c|}
\hline Control: & $\frac{\text { none }}{(1)}$ & $\frac{\text { age }}{(2)}$ & $\frac{\text { married/cohabit }}{(3)}$ & $\begin{array}{c}\begin{array}{c}\text { years of } \\
\text { schooling }\end{array} \\
(4) \\
\end{array}$ & $\frac{\text { employed }}{(5)}$ & $\frac{\text { income }}{(6)}$ \\
\hline \multicolumn{7}{|c|}{ Panel A: Dependent variable is number of partners at Visit 2} \\
\hline Circumcised & $\begin{array}{l}0.236^{*} \\
(0.134)\end{array}$ & $\begin{array}{l}-0.149 \\
(1.162)\end{array}$ & $\begin{array}{l}0.260^{*} \\
(0.139)\end{array}$ & $\begin{array}{c}0.282 \\
(0.417)\end{array}$ & $\begin{array}{c}0.151 \\
(0.147)\end{array}$ & $\begin{array}{c}0.194 \\
(0.143)\end{array}$ \\
\hline Believe & $\begin{array}{c}0.178 \\
(0.117)\end{array}$ & $\begin{array}{c}0.188 \\
(0.123)\end{array}$ & $\begin{array}{c}0.183 \\
(0.119)\end{array}$ & $\begin{array}{c}0.167 \\
(0.117)\end{array}$ & $\begin{array}{c}0.165 \\
(0.118)\end{array}$ & $\begin{array}{c}0.19 \\
(0.119)\end{array}$ \\
\hline Circumcised X Believe & $\begin{array}{l}-0.321^{*} \\
(0.177)\end{array}$ & $\begin{array}{l}-0.321^{*} \\
(0.180)\end{array}$ & $\begin{array}{l}-0.324^{*} \\
(0.177)\end{array}$ & $\begin{array}{l}-0.313^{*} \\
(0.177)\end{array}$ & $\begin{array}{c}-0.302^{*} \\
(0.176)\end{array}$ & $\begin{array}{c}-0.347^{*} \\
(0.178)\end{array}$ \\
\hline Control & -- & $\begin{array}{c}0.020 \\
(0.037)\end{array}$ & $\begin{array}{c}0.308 \\
(0.284)\end{array}$ & $\begin{array}{l}-0.022 \\
(0.021)\end{array}$ & $\begin{array}{c}0.171 \\
(0.119)\end{array}$ & $\begin{array}{c}0.021 \\
(0.018)\end{array}$ \\
\hline Circumcised X Control & -- & $\begin{array}{c}0.019 \\
(0.056)\end{array}$ & $\begin{array}{l}-0.265 \\
(0.379)\end{array}$ & $\begin{array}{l}-0.005 \\
(0.035)\end{array}$ & $\begin{array}{c}0.157 \\
(0.175)\end{array}$ & $\begin{array}{c}0.022 \\
(0.025)\end{array}$ \\
\hline \multicolumn{7}{|c|}{ Panel B: Dependent variable is multiple partners at Visit 2} \\
\hline Circumcised & $\begin{array}{l}0.088^{*} \\
(0.046)\end{array}$ & $\begin{array}{l}-0.296 \\
(0.395)\end{array}$ & $\begin{array}{l}0.094 * \\
(0.048)\end{array}$ & $\begin{array}{c}0.052 \\
(0.152)\end{array}$ & $\begin{array}{c}0.081 \\
(0.054)\end{array}$ & $\begin{array}{c}0.064 \\
(0.052)\end{array}$ \\
\hline Believe & $\begin{array}{c}0.057 \\
(0.042)\end{array}$ & $\begin{array}{c}0.053 \\
(0.043)\end{array}$ & $\begin{array}{c}0.056 \\
(0.042)\end{array}$ & $\begin{array}{c}0.056 \\
(0.043)\end{array}$ & $\begin{array}{c}0.054 \\
(0.042)\end{array}$ & $\begin{array}{c}0.059 \\
(0.042)\end{array}$ \\
\hline Circumcised X Believe & $\begin{array}{c}-0.126^{* *} \\
(0.062)\end{array}$ & $\begin{array}{l}-0.120^{*} \\
(0.063)\end{array}$ & $\begin{array}{c}-0.129^{* *} \\
(0.062)\end{array}$ & $\begin{array}{c}-0.125^{* *} \\
(0.062)\end{array}$ & $\begin{array}{l}-0.122^{*} \\
(0.062)\end{array}$ & $\begin{array}{c}-0.133 * * \\
(0.062)\end{array}$ \\
\hline Control & -- & $\begin{array}{l}-0.007 \\
(0.013)\end{array}$ & $\begin{array}{l}-0.033 \\
(0.075)\end{array}$ & $\begin{array}{l}-0.001 \\
(0.009)\end{array}$ & $\begin{array}{c}0.045 \\
(0.042)\end{array}$ & $\begin{array}{c}0.003 \\
(0.006)\end{array}$ \\
\hline Circumcised X Control & -- & $\begin{array}{c}0.019 \\
(0.019)\end{array}$ & $\begin{array}{l}-0.053 \\
(0.113)\end{array}$ & $\begin{array}{c}0.003 \\
(0.013)\end{array}$ & $\begin{array}{c}0.011 \\
(0.062)\end{array}$ & $\begin{array}{c}0.011 \\
(0.009)\end{array}$ \\
\hline Observations & 998 & 998 & 998 & 998 & 998 & 998 \\
\hline
\end{tabular}

Notes: Circumcised is an indicator variable equal to one if the individual was randomly assigned to receive circumcision. Believe is an indicator variable equal to one if at the beginning of the six month interval over which sexual behavior was recorded the individual reported believing that circumcision reduces the likelihood acquiring HIV. Age measures the respondents age in years. Married/cohabit is an indicator variable. Employed is an indicator variable. Income measures average monthly income in '000's of Kenyan schillings. Number of partners measures the number of sexual partners the repsondent had during the six month period prior to the interview data. Multiple partners is an indicator variable equal to one if the individual had more than one sexual partner during the six month period prior to the interview date. Visit 2 refers to the six month follow-up after the baseline interview. Heteroskedasticityrobust standard errors reported in parentheses.

***Significant at the $1 \%$ level, **Significant at 5\% level, *Significant at $10 \%$ level. 
Table 10: Robustness Checks for Condom Use at Visit 2 to Additional Interactions

\begin{tabular}{|c|c|c|c|c|c|c|}
\hline Control: & $\frac{\text { none }}{(1)}$ & $\frac{\text { age }}{(2)}$ & $\frac{\text { married/cohabit }}{(3)}$ & $\begin{array}{c}\begin{array}{c}\text { years of } \\
\text { schooling }\end{array} \\
(4) \\
\end{array}$ & $\frac{\text { employed }}{(5)}$ & $\begin{array}{c}\text { income } \\
(6) \\
\end{array}$ \\
\hline \multicolumn{7}{|c|}{ Panel A: Dependent variable is "always use condom" at Visit 2} \\
\hline Circumcised & $\begin{array}{l}-0.017 \\
(0.045)\end{array}$ & $\begin{array}{l}-0.082 \\
(0.383)\end{array}$ & $\begin{array}{l}-0.008 \\
(0.045)\end{array}$ & $\begin{array}{c}0.066 \\
(0.153)\end{array}$ & $\begin{array}{l}-0.015 \\
(0.051)\end{array}$ & $\begin{array}{c}-0.04 \\
(0.050)\end{array}$ \\
\hline Believe & $\begin{array}{c}0.018 \\
(0.041)\end{array}$ & $\begin{array}{c}0.011 \\
(0.041)\end{array}$ & $\begin{array}{c}0.013 \\
(0.040)\end{array}$ & $\begin{array}{c}0.037 \\
(0.040)\end{array}$ & $\begin{array}{c}0.031 \\
(0.040)\end{array}$ & $\begin{array}{c}0.01 \\
(0.041)\end{array}$ \\
\hline Circumcised X Believe & $\begin{array}{l}-0.022 \\
(0.060)\end{array}$ & $\begin{array}{l}-0.018 \\
(0.061)\end{array}$ & $\begin{array}{l}-0.035 \\
(0.059)\end{array}$ & $\begin{array}{l}-0.037 \\
(0.059)\end{array}$ & $\begin{array}{l}-0.039 \\
(0.059)\end{array}$ & $\begin{array}{l}-0.012 \\
(0.060)\end{array}$ \\
\hline Control & -- & $\begin{array}{l}-0.014 \\
(0.013)\end{array}$ & $\begin{array}{c}-0.324 * * * \\
(0.073)\end{array}$ & $\begin{array}{c}0.038^{* * *} \\
(0.009)\end{array}$ & $\begin{array}{c}-0.182 * * * \\
(0.040)\end{array}$ & $\begin{array}{c}-0.014 * * * \\
(0.005)\end{array}$ \\
\hline Circumcised X Control & -- & $\begin{array}{c}0.003 \\
(0.018)\end{array}$ & $\begin{array}{l}-0.067 \\
(0.103)\end{array}$ & $\begin{array}{l}-0.007 \\
(0.013)\end{array}$ & $\begin{array}{c}0.013 \\
(0.059)\end{array}$ & $\begin{array}{c}0.007 \\
(0.009)\end{array}$ \\
\hline \multicolumn{7}{|c|}{ Panel B: Dependent variable is "used condom last time" at Visit 2} \\
\hline Circumcised & $\begin{array}{l}-0.016 \\
(0.043)\end{array}$ & $\begin{array}{c}0.004 \\
(0.362)\end{array}$ & $\begin{array}{l}-0.005 \\
(0.042)\end{array}$ & $\begin{array}{l}-0.055 \\
(0.151)\end{array}$ & $\begin{array}{l}-0.001 \\
(0.046)\end{array}$ & $\begin{array}{l}-0.030 \\
(0.047)\end{array}$ \\
\hline Believe & $\begin{array}{c}0.000 \\
(0.039)\end{array}$ & $\begin{array}{l}-0.006 \\
(0.039)\end{array}$ & $\begin{array}{l}-0.006 \\
(0.038)\end{array}$ & $\begin{array}{c}0.017 \\
(0.039)\end{array}$ & $\begin{array}{c}0.012 \\
(0.038)\end{array}$ & $\begin{array}{l}-0.009 \\
(0.039)\end{array}$ \\
\hline Circumcised X Believe & $\begin{array}{l}-0.024 \\
(0.058)\end{array}$ & $\begin{array}{l}-0.021 \\
(0.058)\end{array}$ & $\begin{array}{l}-0.038 \\
(0.056)\end{array}$ & $\begin{array}{l}-0.035 \\
(0.057)\end{array}$ & $\begin{array}{l}-0.040 \\
(0.056)\end{array}$ & $\begin{array}{l}-0.011 \\
(0.057)\end{array}$ \\
\hline Control & -- & $\begin{array}{l}-0.012 \\
(0.012)\end{array}$ & $\begin{array}{c}-0.340 * * * \\
(0.075)\end{array}$ & $\begin{array}{c}0.033 * * * \\
(0.009)\end{array}$ & $\begin{array}{c}-0.171 * * * \\
(0.038)\end{array}$ & $\begin{array}{c}-0.015 * * * \\
(0.005)\end{array}$ \\
\hline Circumcised X Control & -- & $\begin{array}{l}-0.001 \\
(0.018)\end{array}$ & $\begin{array}{l}-0.093 \\
(0.107)\end{array}$ & $\begin{array}{c}0.004 \\
(0.013)\end{array}$ & $\begin{array}{l}-0.015 \\
(0.057)\end{array}$ & $\begin{array}{c}0.003 \\
(0.009)\end{array}$ \\
\hline Observations & 998 & 998 & 998 & 998 & 998 & 998 \\
\hline
\end{tabular}

Notes: Circumcised is an indicator variable equal to one if the individual was randomly assigned to receive circumcision. Believe is an indicator variable equal to one if at the beginning of the six month interval over which sexual behavior was recorded the individual reported believing that circumcision reduces the likelihood acquiring HIV. Age measures the respondents age in years. Married/cohabit is an indicator variable. Employed is an indicator variable. Income measures average monthly income in '000's of Kenyan schillings. Always use condom measures the fraction of partners with whom the respondent reported always using a condom. Used condom last time measures the fraction of partners with whom the respondent reported using a condom during their last sexual encounter. Visit 2 refers to the six month follow-up after the baseline interview. Heteroskedasticity-robust standard errors reported in parentheses.

***Significant at the $1 \%$ level, **Significant at $5 \%$ level, *Significant at $10 \%$ level. 
Table 11: Robustness Checks for Partnerships at Visit 3 to Additional Interactions

\begin{tabular}{|c|c|c|c|c|c|c|}
\hline Control: & $\frac{\text { none }}{(1)}$ & $\frac{\text { age }}{(2)}$ & $\frac{\text { married/cohabit }}{(3)}$ & $\begin{array}{c}\begin{array}{c}\text { years of } \\
\text { schooling }\end{array} \\
(4) \\
\end{array}$ & $\frac{\text { employed }}{(5)}$ & $\frac{\text { income }}{(6)}$ \\
\hline \multicolumn{7}{|c|}{ Panel A: Dependent variable is number of partners at Visit 3} \\
\hline Circumcised & $\begin{array}{l}0.328 * * \\
(0.162)\end{array}$ & $\begin{array}{l}-0.782 \\
(1.082)\end{array}$ & $\begin{array}{c}0.367^{* *} \\
(0.157)\end{array}$ & $\begin{array}{c}0.339 \\
(0.455)\end{array}$ & $\begin{array}{c}0.359^{* *} \\
(0.179)\end{array}$ & $\begin{array}{l}0.295^{*} \\
(0.165)\end{array}$ \\
\hline Believe & $\begin{array}{l}0.251^{*} \\
(0.147)\end{array}$ & $\begin{array}{l}0.252 * \\
(0.147)\end{array}$ & $\begin{array}{c}0.231 \\
(0.149)\end{array}$ & $\begin{array}{l}0.244^{*} \\
(0.148)\end{array}$ & $\begin{array}{c}0.229 \\
(0.148)\end{array}$ & $\begin{array}{c}0.241 \\
(0.149)\end{array}$ \\
\hline Circumcised X Believe & $\begin{array}{c}-0.537 * * * \\
(0.197)\end{array}$ & $\begin{array}{c}-0.526^{* * *} \\
(0.196)\end{array}$ & $\begin{array}{c}-0.518^{* * *} \\
(0.199)\end{array}$ & $\begin{array}{c}-0.533 * * * \\
(0.197)\end{array}$ & $\begin{array}{c}-0.521 * * * \\
(0.197)\end{array}$ & $\begin{array}{c}-0.537 * * * \\
(0.198)\end{array}$ \\
\hline Control & -- & $\begin{array}{c}0.016 \\
(0.037)\end{array}$ & $\begin{array}{c}0.486 \\
(0.342)\end{array}$ & $\begin{array}{l}-0.017 \\
(0.028)\end{array}$ & $\begin{array}{l}0.258^{*} \\
(0.141)\end{array}$ & $\begin{array}{c}0.016 \\
(0.020)\end{array}$ \\
\hline Circumcised X Control & -- & $\begin{array}{c}0.054 \\
(0.053)\end{array}$ & $\begin{array}{l}-0.476 \\
(0.363)\end{array}$ & $\begin{array}{l}-0.001 \\
(0.039)\end{array}$ & $\begin{array}{l}-0.072 \\
(0.185)\end{array}$ & $\begin{array}{c}0.013 \\
(0.025)\end{array}$ \\
\hline \multicolumn{7}{|c|}{ Panel B: Dependent variable is multiple partners at Visit 3} \\
\hline Circumcised & $\begin{array}{c}0.128^{* *} \\
(0.060)\end{array}$ & $\begin{array}{l}-0.456 \\
(0.413)\end{array}$ & $\begin{array}{l}0.118^{*} \\
(0.061)\end{array}$ & $\begin{array}{l}-0.005 \\
(0.166)\end{array}$ & $\begin{array}{l}0.116^{*} \\
(0.066)\end{array}$ & $\begin{array}{c}0.092 \\
(0.063)\end{array}$ \\
\hline Believe & $\begin{array}{c}0.058 \\
(0.049)\end{array}$ & $\begin{array}{c}0.058 \\
(0.049)\end{array}$ & $\begin{array}{c}0.063 \\
(0.049)\end{array}$ & $\begin{array}{c}0.054 \\
(0.049)\end{array}$ & $\begin{array}{c}0.056 \\
(0.049)\end{array}$ & $\begin{array}{c}0.058 \\
(0.049)\end{array}$ \\
\hline Circumcised X Believe & $\begin{array}{c}-0.180^{* *} \\
(0.072)\end{array}$ & $\begin{array}{c}-0.176^{* *} \\
(0.072)\end{array}$ & $\begin{array}{c}-0.186 * * * \\
(0.072)\end{array}$ & $\begin{array}{c}-0.176^{* *} \\
(0.072)\end{array}$ & $\begin{array}{c}-0.180^{* *} \\
(0.072)\end{array}$ & $\begin{array}{c}-0.186^{* * *} \\
(0.071)\end{array}$ \\
\hline Control & -- & $\begin{array}{l}-0.005 \\
(0.014)\end{array}$ & $\begin{array}{c}-0.134 * * \\
(0.067)\end{array}$ & $\begin{array}{l}-0.009 \\
(0.010)\end{array}$ & $\begin{array}{c}0.021 \\
(0.046)\end{array}$ & $\begin{array}{c}0.00 \\
(0.005)\end{array}$ \\
\hline Circumcised X Control & -- & $\begin{array}{c}0.028 \\
(0.020)\end{array}$ & $\begin{array}{c}0.128 \\
(0.100)\end{array}$ & $\begin{array}{c}0.012 \\
(0.014)\end{array}$ & $\begin{array}{c}0.026 \\
(0.066)\end{array}$ & $\begin{array}{l}0.015^{*} \\
(0.009)\end{array}$ \\
\hline Observations & 867 & 867 & 867 & 867 & 867 & 867 \\
\hline
\end{tabular}

Notes: Circumcised is an indicator variable equal to one if the individual was randomly assigned to receive circumcision. Believe is an indicator variable equal to one if at the beginning of the six month interval over which sexual behavior was recorded the individual reported believing that circumcision reduces the likelihood acquiring HIV. Age measures the respondents age in years. Married/cohabit is an indicator variable. Employed is an indicator variable. Income measures average monthly income in '000's of Kenyan schillings. Number of partners measures the number of sexual partners the repsondent had during the six month period prior to the interview data. Multiple partners is an indicator variable equal to one if the individual had more than one sexual partner during the six month period prior to the interview date. Visit 3 refers to the twelve month follow-up after the baseline interview. Heteroskedasticity-robust standard errors reported in parentheses.

*** Significant at the $1 \%$ level, $* *$ Significant at $5 \%$ level, *Significant at $10 \%$ level.A48 
Table 12: Robustness Checks for Condom Use at Visit 3 to Additional Interactions

\begin{tabular}{|c|c|c|c|c|c|c|}
\hline Control: & $\begin{array}{c}\text { none } \\
(1) \\
\end{array}$ & $\frac{\text { age }}{(2)}$ & $\frac{\text { married/cohabit }}{(3)}$ & $\begin{array}{c}\begin{array}{c}\text { years of } \\
\text { schooling }\end{array} \\
(4) \\
\end{array}$ & $\frac{\text { employed }}{(5)}$ & $\frac{\text { income }}{(6)}$ \\
\hline \multicolumn{7}{|c|}{ Panel A: Dependent variable is "always use condom" at Visit 3} \\
\hline Circumcised & $\begin{array}{c}-0.149 * * * \\
(0.056)\end{array}$ & $\begin{array}{c}0.239 \\
(0.393)\end{array}$ & $\begin{array}{c}-0.127 * * \\
(0.055)\end{array}$ & $\begin{array}{l}-0.003 \\
(0.164)\end{array}$ & $\begin{array}{c}-0.166^{* * *} \\
(0.063)\end{array}$ & $\begin{array}{c}-0.154^{* * * *} \\
(0.058)\end{array}$ \\
\hline Believe & $\begin{array}{l}-0.082^{*} \\
(0.046)\end{array}$ & $\begin{array}{l}-0.081^{*} \\
(0.046)\end{array}$ & $\begin{array}{l}-0.062 \\
(0.043)\end{array}$ & $\begin{array}{l}-0.068 \\
(0.045)\end{array}$ & $\begin{array}{l}-0.067 \\
(0.045)\end{array}$ & $\begin{array}{l}-0.074 \\
(0.046)\end{array}$ \\
\hline Circumcised X Believe & $\begin{array}{l}0.116^{*} \\
(0.068)\end{array}$ & $\begin{array}{l}0.113^{*} \\
(0.068)\end{array}$ & $\begin{array}{c}0.091 \\
(0.065)\end{array}$ & $\begin{array}{c}0.105 \\
(0.067)\end{array}$ & $\begin{array}{c}0.105 \\
(0.068)\end{array}$ & $\begin{array}{c}0.111 \\
(0.068)\end{array}$ \\
\hline Control & -- & $\begin{array}{c}0.007 \\
(0.013)\end{array}$ & $\begin{array}{c}-0.499 * * * \\
(0.060)\end{array}$ & $\begin{array}{c}0.036^{* * *} \\
(0.009)\end{array}$ & $\begin{array}{c}-0.182 * * * \\
(0.042)\end{array}$ & $\begin{array}{c}-0.013 * * * \\
(0.004)\end{array}$ \\
\hline Circumcised X Control & -- & $\begin{array}{l}-0.019 \\
(0.019)\end{array}$ & $\begin{array}{l}-0.012 \\
(0.079)\end{array}$ & $\begin{array}{l}-0.013 \\
(0.014)\end{array}$ & $\begin{array}{c}0.041 \\
(0.063)\end{array}$ & $\begin{array}{c}0.003 \\
(0.007)\end{array}$ \\
\hline \multicolumn{7}{|c|}{ Panel B: Dependent variable is "used condom last time" at Visit 3} \\
\hline Circumcised & $\begin{array}{c}-0.145 * * * \\
(0.054)\end{array}$ & $\begin{array}{c}0.202 \\
(0.382)\end{array}$ & $\begin{array}{c}-0.124 * * \\
(0.053)\end{array}$ & $\begin{array}{c}0.001 \\
(0.160)\end{array}$ & $\begin{array}{c}-0.131^{* *} \\
(0.060)\end{array}$ & $\begin{array}{c}-0.153 * * * \\
(0.057)\end{array}$ \\
\hline Believe & $\begin{array}{c}-0.097 * * \\
(0.043)\end{array}$ & $\begin{array}{c}-0.097 * * \\
(0.043)\end{array}$ & $\begin{array}{l}-0.076^{*} \\
(0.040)\end{array}$ & $\begin{array}{l}-0.083^{*} \\
(0.043)\end{array}$ & $\begin{array}{l}-0.084 * \\
(0.043)\end{array}$ & $\begin{array}{c}-0.089^{* *} \\
(0.043)\end{array}$ \\
\hline Circumcised X Believe & $\begin{array}{c}0.140^{* *} \\
(0.066)\end{array}$ & $\begin{array}{c}0.137^{* *} \\
(0.066)\end{array}$ & $\begin{array}{l}0.114 * \\
(0.063)\end{array}$ & $\begin{array}{l}0.130^{* *} \\
(0.065)\end{array}$ & $\begin{array}{c}0.132^{* *} \\
(0.065)\end{array}$ & $\begin{array}{c}0.135^{* *} \\
(0.066)\end{array}$ \\
\hline Control & -- & $\begin{array}{c}0.005 \\
(0.012)\end{array}$ & $\begin{array}{c}-0.544^{* * * *} \\
(0.059)\end{array}$ & $\begin{array}{c}0.036^{* * *} \\
(0.009)\end{array}$ & $\begin{array}{c}-0.159^{* * * *} \\
(0.041)\end{array}$ & $\begin{array}{c}-0.014 * * * \\
(0.004)\end{array}$ \\
\hline Circumcised X Control & -- & $\begin{array}{l}-0.017 \\
(0.018)\end{array}$ & $\begin{array}{c}0.01 \\
(0.082)\end{array}$ & $\begin{array}{l}-0.013 \\
(0.013)\end{array}$ & $\begin{array}{l}-0.027 \\
(0.060)\end{array}$ & $\begin{array}{c}0.004 \\
(0.007)\end{array}$ \\
\hline Observations & 867 & 867 & 867 & 867 & 867 & 867 \\
\hline
\end{tabular}

Notes: Circumcised is an indicator variable equal to one if the individual was randomly assigned to receive circumcision. Believe is an indicator variable equal to one if at the beginning of the six month interval over which sexual behavior was recorded the individual reported believing that circumcision reduces the likelihood acquiring HIV. Age measures the respondents age in years. Married/cohabit is an indicator variable. Employed is an indicator variable. Income measures average monthly income in '000's of Kenyan schillings. Always use condom measures the fraction of partners with whom the respondent reported always using a condom. Used condom last time measures the fraction of partners with whom the respondent reported using a condom during their last sexual encounter. Visit 3 refers to the twelve month follow-up after the baseline interview. Heteroskedasticity-robust standard errors reported in parentheses. ***Significant at the $1 \%$ level, **Significant at $5 \%$ level, *Significant at $10 \%$ level. 
Table 13: Average Response to Circumcision

\begin{tabular}{|c|c|c|c|c|c|c|c|c|}
\hline \multirow{2}{*}{$\begin{array}{l}\text { Visit: } \\
\text { Dependent variable: }\end{array}$} & \multicolumn{4}{|c|}{ visit 2} & \multicolumn{4}{|c|}{ visit 3} \\
\hline & $\begin{array}{c}\begin{array}{c}\text { number of } \\
\text { partners }\end{array} \\
(1)\end{array}$ & $\begin{array}{c}\begin{array}{l}\text { multiple } \\
\text { partners }\end{array} \\
(2)\end{array}$ & $\begin{array}{l}\begin{array}{c}\text { always use } \\
\text { condom }\end{array} \\
(3)\end{array}$ & $\begin{array}{c}\text { used condom } \\
\text { last time }\end{array}$ & $\begin{array}{c}\begin{array}{c}\text { number of } \\
\text { partners }\end{array} \\
(5)\end{array}$ & $\begin{array}{c}\begin{array}{l}\text { multiple } \\
\text { partners }\end{array} \\
(6)\end{array}$ & $\begin{array}{l}\begin{array}{c}\text { always use } \\
\text { condom }\end{array} \\
(7)\end{array}$ & $\begin{array}{c}\begin{array}{l}\text { used condom } \\
\text { last time }\end{array} \\
(8)\end{array}$ \\
\hline \multicolumn{9}{|l|}{ Panel A: No controls } \\
\hline Circumcised & $\begin{array}{c}0.057 \\
(0.087)\end{array}$ & $\begin{array}{c}0.018 \\
(0.031)\end{array}$ & $\begin{array}{l}-0.029 \\
(0.030)\end{array}$ & $\begin{array}{l}-0.029 \\
(0.029)\end{array}$ & $\begin{array}{l}-0.044 \\
(0.093)\end{array}$ & $\begin{array}{c}0.004 \\
(0.033)\end{array}$ & $\begin{array}{c}-0.068^{* *} \\
(0.032)\end{array}$ & $\begin{array}{c}-0.047 \\
(0.031)\end{array}$ \\
\hline \multicolumn{9}{|c|}{ Panel B: Controlling for belief } \\
\hline Circumcised & $\begin{array}{c}0.057 \\
(0.088)\end{array}$ & $\begin{array}{c}0.018 \\
(0.031)\end{array}$ & $\begin{array}{l}-0.029 \\
(0.030)\end{array}$ & $\begin{array}{l}-0.029 \\
(0.029)\end{array}$ & $\begin{array}{l}-0.044 \\
(0.093)\end{array}$ & $\begin{array}{c}0.003 \\
(0.033)\end{array}$ & $\begin{array}{c}-0.069^{* *} \\
(0.032)\end{array}$ & $\begin{array}{l}-0.048 \\
(0.031)\end{array}$ \\
\hline Believe & $\begin{array}{c}0.024 \\
(0.088)\end{array}$ & $\begin{array}{l}-0.006 \\
(0.031)\end{array}$ & $\begin{array}{c}0.007 \\
(0.030)\end{array}$ & $\begin{array}{l}-0.011 \\
(0.029)\end{array}$ & $\begin{array}{l}-0.009 \\
(0.100)\end{array}$ & $\begin{array}{l}-0.029 \\
(0.036)\end{array}$ & $\begin{array}{l}-0.026 \\
(0.034)\end{array}$ & $\begin{array}{l}-0.030 \\
(0.033)\end{array}$ \\
\hline \multicolumn{9}{|c|}{ Panel C: Additional controls } \\
\hline Circumcised & $\begin{array}{c}0.059 \\
(0.087)\end{array}$ & $\begin{array}{c}0.018 \\
(0.031)\end{array}$ & $\begin{array}{l}-0.033 \\
(0.029)\end{array}$ & $\begin{array}{l}-0.033 \\
(0.027)\end{array}$ & $\begin{array}{l}-0.040 \\
(0.093)\end{array}$ & $\begin{array}{c}0.005 \\
(0.033)\end{array}$ & $\begin{array}{c}-0.071 * * \\
(0.030)\end{array}$ & $\begin{array}{l}-0.050^{*} \\
(0.028)\end{array}$ \\
\hline Believe & $\begin{array}{c}0.023 \\
(0.091)\end{array}$ & $\begin{array}{l}-0.009 \\
(0.031)\end{array}$ & $\begin{array}{c}0.009 \\
(0.029)\end{array}$ & $\begin{array}{l}-0.011 \\
(0.028)\end{array}$ & $\begin{array}{l}-0.028 \\
(0.100)\end{array}$ & $\begin{array}{l}-0.032 \\
(0.036)\end{array}$ & $\begin{array}{l}-0.003 \\
(0.032)\end{array}$ & $\begin{array}{l}-0.006 \\
(0.031)\end{array}$ \\
\hline Age & $\begin{array}{c}0.013 \\
(0.027)\end{array}$ & $\begin{array}{l}-0.001 \\
(0.010)\end{array}$ & $\begin{array}{c}-0.002 \\
(0.009)\end{array}$ & $\begin{array}{l}-0.002 \\
(0.009)\end{array}$ & $\begin{array}{c}0.022 \\
(0.030)\end{array}$ & $\begin{array}{c}0.009 \\
(0.011)\end{array}$ & $\begin{array}{c}0.019^{* *} \\
(0.009)\end{array}$ & $\begin{array}{c}0.019^{* *} \\
(0.009)\end{array}$ \\
\hline Married/cohabit & $\begin{array}{c}0.079 \\
(0.211)\end{array}$ & $\begin{array}{l}-0.075 \\
(0.059)\end{array}$ & $\begin{array}{c}-0.284 * * * \\
(0.053)\end{array}$ & $\begin{array}{c}-0.309^{* * *} \\
(0.055)\end{array}$ & $\begin{array}{c}0.148 \\
(0.192)\end{array}$ & $\begin{array}{c}-0.101 * \\
(0.054)\end{array}$ & $\begin{array}{c}-0.472 * * * \\
(0.043)\end{array}$ & $\begin{array}{c}-0.505^{* * *} \\
(0.044)\end{array}$ \\
\hline Years of schooling & $\begin{array}{l}-0.016 \\
(0.018)\end{array}$ & $\begin{array}{c}0.001 \\
(0.007)\end{array}$ & $\begin{array}{c}0.024 * * * \\
(0.007)\end{array}$ & $\begin{array}{c}0.025 * * * \\
(0.006)\end{array}$ & $\begin{array}{l}-0.012 \\
(0.021)\end{array}$ & $\begin{array}{l}-0.005 \\
(0.007)\end{array}$ & $\begin{array}{c}0.018^{* * * *} \\
(0.007)\end{array}$ & $\begin{array}{c}0.017 * * * \\
(0.006)\end{array}$ \\
\hline Employed & $\begin{array}{l}0.177^{*} \\
(0.101)\end{array}$ & $\begin{array}{c}0.054 \\
(0.035)\end{array}$ & $\begin{array}{c}-0.096 * * * \\
(0.032)\end{array}$ & $\begin{array}{c}-0.090 * * * \\
(0.031)\end{array}$ & $\begin{array}{l}0.165^{*} \\
(0.099)\end{array}$ & $\begin{array}{c}0.037 \\
(0.036)\end{array}$ & $\begin{array}{c}-0.071 * * \\
(0.032)\end{array}$ & $\begin{array}{c}-0.075^{* *} \\
(0.031)\end{array}$ \\
\hline Income & $\begin{array}{c}0.019 \\
(0.013)\end{array}$ & $\begin{array}{c}0.006 \\
(0.006)\end{array}$ & $\begin{array}{l}-0.006 \\
(0.004)\end{array}$ & $\begin{array}{c}-0.009 * * \\
(0.004)\end{array}$ & $\begin{array}{c}0.014 \\
(0.012)\end{array}$ & $\begin{array}{c}0.005 \\
(0.005)\end{array}$ & $\begin{array}{c}-0.008 * * * \\
(0.003)\end{array}$ & $\begin{array}{c}-0.008 * * * \\
(0.003)\end{array}$ \\
\hline Observations & 998 & 998 & 998 & 998 & 867 & 867 & 867 & 867 \\
\hline
\end{tabular}

Notes: Circumcised is an indicator variable equal to one if the individual was randomly assigned to receive circumcision.

Believe is an indicator variable equal to one if at the beginning of the six month interval over which sexual behavior was recorded the individual reported believing that circumcision reduces the likelihood acquiring HIV. Age measures the respondents age in years. Married/cohabit is an indicator variable. Employed is an indicator variable. Income measures average monthly income in '000's of Kenyan schillings. Number of partners measures the number of sexual partners the repsondent had during the six month period prior to the interview data. Multiple partners is an indicator variable equal to one if the individual had more than one sexual partner during the six month period prior to the interview date. Always use condom measures the fraction of partners with whom the respondent reported always using a condom. Used condom last time measures the fraction of partners with whom the respondent reported using a condom during their last sexual encounter. Visit 2 refers to the six month follow-up after the baseline interview. Visit 3 refers to the twelve month follow-up after the baseline interview.

Heteroskedasticity-robust standard errors reported in parentheses.

***Significant at the $1 \%$ level, ${ }^{*}$ Significant at $5 \%$ level, $*$ Significant at $10 \%$ level. 